\title{
Investigating the Impacts of Intraregional Trade and Aid on Per Capita Income in Africa: Case Study of the ECOWAS
}

\begin{abstract}
Assandé Désiré Adom
Department of Economics, Eastern Illinois University, 600 Lincoln Avenue, Charleston, IL 61920, USA

Correspondence should be addressed to Assandé Désiré Adom, aadom@eiu.edu

Received 27 March 2012; Revised 26 May 2012; Accepted 5 June 2012

Academic Editor: Sajal Lahiri

Copyright ( $) 2012$ Assandé Désiré Adom. This is an open access article distributed under the Creative Commons Attribution License, which permits unrestricted use, distribution, and reproduction in any medium, provided the original work is properly cited.

In the past 50 years, a striking stylized fact has been the downward—or flat—-trend of intra-African trade as a share of Africa's total trade, while official development assistance (ODA) has experienced a noticeable expansion. During the same period, economic growth performances have not been consistent and robust enough to put a dent in the poverty level across the African continent in general and the Economic Community of West African States (ECOWAS) in particular. Using a two-stage least square (TSLS) estimation technique, this paper finds out that intra-ECOWAS trade stimulates per capita income growth substantially more than foreign aid, which rather constitutes an impediment to that growth in most specifications. Additionally, comparable results are obtained when the scope of the study is expanded to include trade of ECOWAS members with the rest of the world. As a result, it becomes appropriate to suggest policy recommendations encouraging increased cooperation among member states in an attempt to (i) expand and build new cross-states infrastructures, aimed at boosting communications and telecommunications networks, (ii) accelerate the trade facilitation process by addressing administrative red tapes that balloon both transaction costs and delays in the flows of goods across borders, seaports, and airports, and (iii) develop and diversify the industrial base in member states.
\end{abstract}

\section{Introduction}

"Can foreign aid buy growth?" This was the insightful interrogation addressed by Easterly [1] in a study relating to the effectiveness of aid in developing countries. With this contribution, Easterly joined the debate on the relationship between aid, policy, and growth, which was spurred by a seminal paper by Burnside and Dollar [2]. According to figures published by the United Nations Conference on Trade and Development (UNCTAD), global trade has experienced a 7 -fold increase since 1980. During the same period, Africa's share of global trade has fallen from about 11 percent to less than 7 percent in 2009 (Figure 1), while foreign aid has noticeably increased both in volume and as a share of GDP. Three other stylized facts further deserve attention. First, the continent abounds in riches such as raw materials, whether mineral or agricultural. Second, the continent's growth performances generally remained anemic until the beginning of the year 2000s. Third, it is a continent that presents a bleak picture with one of the highest level of poverty in the world.
Accordingly, any effort destined to understand the reasons why the African continent still remains at the margins of both global trade and economic development becomes worthwhile. Many observers and scholars have opined on whether or not aid has in effect helped developing countries achieve economic growth, which is a necessary-but not a sufficient-condition to successfully alleviate the scourges of poverty.

For decades following their independence, the growing inflow of foreign aid has nurtured a culture of financial dependency and mal governance that have not proved helpful in promoting economic growth in a long list of African countries. On the average, the level of foreign aid as a percentage of GDP for a sub-Saharan African state is more than 4 times the one of countries in other regions of the globe. Furthermore, the volume of aid in that region was as high as $\$ 35$ per person in the 1990s [3, page 11]. These countries have not developed and implemented effective trade policies to generate revenue on their own as a consequence of their heavy reliance on foreign aid. The vast amount of aid pouring 


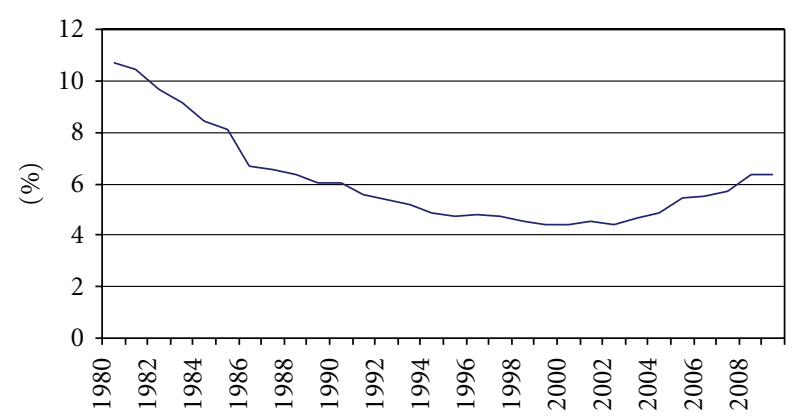

FIGURE 1: Share of Africa in world trade from 1980 to 2009 (source: UNCTAD).

in has tamed any incentives to improve infrastructure- such as roads, ports, electric grids, among others-and undertake critical administrative reforms to support trade.

Ilorah [4] clearly identifies trade as a critical factor for economic growth. At the same time, he explains that foreign aid is an inhibitor of economic growth because of its pervasive byproducts which are multiform. Indeed, ills such as corruption and the quasiabsence of strong domestic Institutions, that foster democracy and the rule of law, are commonplace in African countries. It is noteworthy that foreign aid remittances remain a chief factor that perpetuates the deeply entrenched patronage system in many African countries [5, page 32]. It is a stylized fact across the globe that countries that have experienced sustained economic growth and prosperity have done so through a continued expansion and embrace of trade with other countries.

Economic history on the other hand teaches the importance of trade in any country's development process. The BRICS (BRIC is an acronym originally coined in 2003 by Jim O'Neill of Goldman Sachs to represent Brazil, Russia, India and China as the most powerful emerging countries to be reckoned with in the future. South Africa joined the group in 2010, thus the current five-letter form of BRIC) countries represent an eloquent contemporary illustration of this fact. Through trade, they have generated substantial revenues that have contributed to their lifting hundreds of millions of their citizens out of poverty. Economic history also teaches us that countries that have been the most active players in global trade have enjoyed a high level of standard of living. Trade also generates a great deal of positive externalities as it stimulates investment and knowledge transfer [4].

In the literature, ample evidence found across continents indicates that aid to developing countries is inefficient in boosting economic growth. In Bangladesh, for instance, Quazi [6] utilizes cointegration techniques in a neoclassical growth setting and uncovers that the effects of aid on GDP growth are marginal. Although this study does not explicitly account for the quality of policy, its results are comparable to many others in the literature. Burnside and Dollar [2] build a modified neoclassical growth model that controls for the policy environment in the recipient country. A two-stage least square estimation technique applied to 56 countries reveals that aid is ineffective in promoting growth in developing countries with poor policies.
This finding puts the inefficiency of aid in developing countries in sharp focus mainly due to the fact that most developing countries present an environment where policies are poorly implemented. Indeed, most of these countries are marred by corruption, embezzlement, and clientelism at the highest echelons of both government and the civil service architecture. It is therefore most likely that aid will become an ineffective determinant of economic growth in such an environment. It may be argued that this environment is an offshoot of a low level of human capital among decision makers. However, one should exercise caution when holding this argument because there have been instances of well- and western-educated decision makers who have succombed to the temptations of corruption, embezzlements, and clientelism once appointed or elected to prominent positions. The bottom line, in our view, is that the low level of human capital can hardly be the root cause that explains in its entirety the long-lasting and current status quo.

On the other hand, Frankel and Romer [7] have developed a three-equation model to capture the determinants of income per capita, international trade, and intracountry trade. With a set of 63 countries, both developing and developed, the authors' findings reinforce the view that trade is paramount in the economic development of a nation. Their study points out that the effect of trade on income per capita is robust, positive, and statistically significant.

Our paper investigates the impacts of both intraECOWAS trade and aid on per capita income. It is an attempt to provide empirical evidence that developing countries of ECOWAS should direct their efforts toward implementing policies that promote intra-ECOWAS trade rather than rely on aid. Foreign aid allocations are less driven by the recipient countries economic fundamentals and needs than by the donor countries' coveted interests. As a matter of fact, donor countries extend bilateral aid not out of "altruism" but in consideration of potential trade benefits for their domestic industries as shown through a comprehensive study by Younas [8]. He has come to this conclusion after considering net official development assistance (ODA) provided by 22 Development Assistance Committee (DAC) member countries of OECD to 78 recipient countries.

In another study, Younas and Bandyopadhyay [9] have established from a different perspective that aid is not allocated to recipient countries to compensate them for lost trade revenue, nor is it allocated to reward them for adopting "freer trade regimes." In other words, aid allocations by donors are motivated by factors that do not necessarily incorporate recipient countries' interests. The previous two studies reinforce our argument that developing countries, especially those in the ECOWAS, should explore ways to reduce their dependency on foreign aid, which as a general rule is not primarily geared toward promoting their economic interests. This situation in turn makes it unlikely that foreign aid will stimulate income per capita and be impactful in the fight against poverty.

Our work singularizes itself in two ways. First, it focuses on developing countries of Africa in general and ECOWAS, in particular. Such an approach addresses specific matters pertaining to these economies. Second, it utilizes a two-stage 
least squares process that considers intra-ECOWAS trade as an endogenous variable. This method reduces endogeneity problems by including the determinants of intra-ECOWAS trade in the main baseline model. As a result, it provides stronger results regarding the effects of the determinants of per capita income in the ECOWAS.

Our results show that intra-ECOWAS trade is a growth driver in most variants of our baseline model. It is strongly significant with the expected positive sign. On the other hand, aid appears as an impediment to per capita income expansion by consistently displaying a significant and negative sign in most specifications. Besides, this work finds comparable results when it is expanded to include trade of ECOWAS members with the rest of the world. These findings send some signals, which have practical implications, to ECOWAS decision makers. They are indeed encouraged to introduce and implement policies that reduce their heavy reliance on aid. Evidence indeed suggests that it is a growth inhibitor, and it compromises their quest for more financial independence vis-à-vis donor countries.

Toward our goals, the present paper is structured around five parts. The second part provides a background regarding the ECOWAS, intraregional trade, and aid. In the third part, the methodology and data are presented, while the fourth part discusses the results and policy implications. At last, concluding remarks are made in the fifth part.

\section{The ECOWAS, Trade, and Aid: Then and Now}

The leaders of nations in West Africa established the Economic Community of West African States (ECOWAS) in 1975. It was created to promote region-wide economic integration among the 15 member states, which are Benin, Burkina Faso, Cape Verde, Côte d'Ivoire, Gambia, Ghana, Guinea, Guinea-Bissau, Liberia, Mali, Niger, Nigeria, Senegal, Sierra Leone, and Togo. Since its inception, this association has been striving to develop intraregional trade which has been dismal for decades. Among the major programs set up to achieve this goal, one may identify the ECOWAS Trade Liberalization Scheme (ETLS). It is a program aimed at creating a customs union by (i) eliminating customs duties and taxes of equivalent effects, (ii) removing nontariff barriers, and (iii) establishing a Common Customs External Tariff to protect goods produced by member states.

In the past 30 years, intra-ECOWAS trade has hovered between 5 and 18 percent of ECOWAS member countries total trade (Figure 2). On the average, this share was 14 percent over this period. Despite this relatively modest figure, it is worth highlighting some glimmer of satisfaction regarding intra-ECOWAS trade. Indeed, this figure reveals that intraECOWAS trade has been trending upward, notwithstanding the fact that it still represents a small share of total trade.

Efforts to expand trade in the ECOWAS must be far reaching and garner the full support of regional leaders. It is essential to create an environment- through trade policy reforms and infrastructure development-that will foster an active participation in international trade in general and regional trade in particular. In addition to the ETLS, the ECOWAS has endorsed the Aid for Trade (AfT) initiative

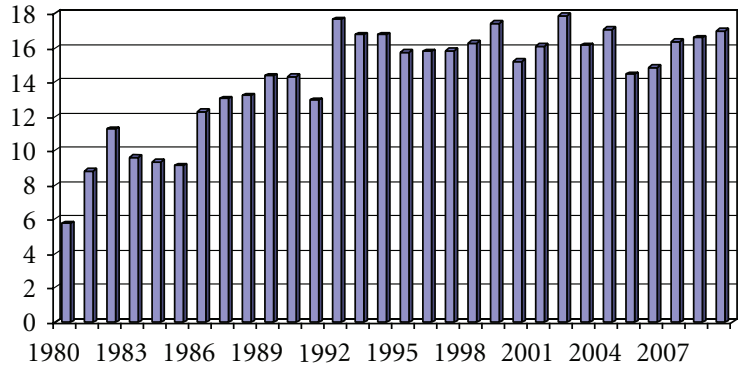

FIGURE 2: Share of Intra-ECOWAS trade (relative to total trade. Liberia is excluded due to lack of data) (in percentage) (source: UNCTAD).

introduced by the World Trade Organization (WTO) in 2005. Overall, this initiative is meant to help "build the trade capacity and infrastructure" needed by developing countries to "benefit from trade opening." Six categories of recommendation are identified by the AfT. They pertain to (i) the development of economic infrastructure, (ii) the building of productive capacity, (iii) the implementation of cost adjustment policies, (iv) the design of an efficient trade policy and regulations, (v) the development of trade, and (vi) a comprehensive approach that deals with other trade-related needs.

Foreign aid has averaged $\$ 33$ per capita in the ECOWAS. Since the year 2000, there has been an increase in this figure with a peak at $\$ 66$ between 2007 and 2008. It followed a decline that took place in the 1990s (Figure 3). A careful look at the data from individual countries' standpoints is very revealing. For instance, Cape Verde averaged about $\$ 400$ in foreign aid per capita, while countries like Sierra Leone, Guinea-Bissau, and Gambia reached about \$200, \$133 and $\$ 107$, respectively (Table 1 ). Another fact that deserves attention is that net official development assistance (ODA) as a share of investment has been substantial in the ECOWAS. In 1992, this share peaked at about 150 percent with the lowest share being in 2004 at about 30 percent. One has been observing a downward trend in that figure since 1980 . With a 30-year average that tops 90 percent, it will be in the region's interests if decision makers could implement policies that maintain and accelerate this trend (Figure 4). Indeed, the figure of 90 percent eloquently underscores the high dependence of these countries on foreign aid.

\section{Methodology and Data Description}

Our investigation of the impacts of aid and intraregional trade on per capita income is articulated around two baseline models that include two equations each. The first baseline model (bmod1, hereafter) - which is the main modelincludes (1) and (2). The second baseline model (bmod2, hereafter) is described by (3) and (4). The latter model, bmod2, is introduced in this work in an attempt to broaden the scope of our conclusions and deepen our understanding 


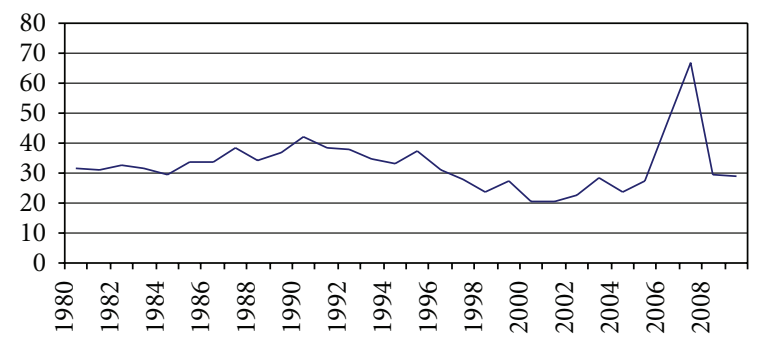

FIgURe 3: Net ODA per capita in the ECOWAS (with the exclusion of Liberia due to lack of data.) (source: World Bank).

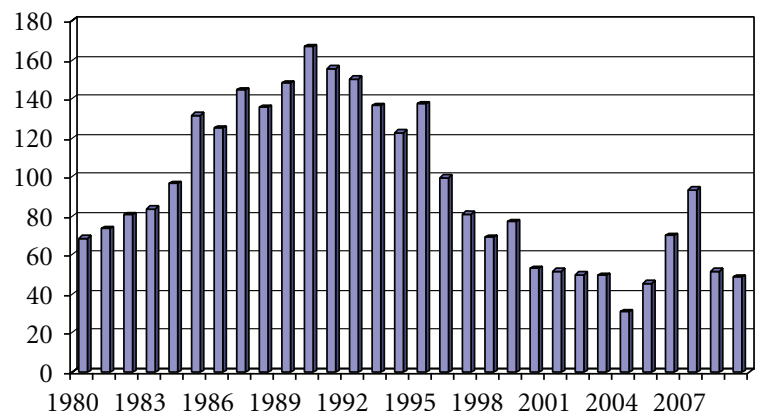

Figure 4: Net ODA as a share of gross fixed capital formation (With the exclusion of Liberia due to lack of data.) (in percentage) (source: World Bank).

of the effects of aid and trade, in general, on per capita income in ECOWAS developing countries.

$$
\begin{aligned}
w_{i t} & =\lambda_{11}+\delta_{11} S_{i t}+\theta_{11} N_{i t}+\pi_{11} L_{i t}+\omega_{i t}, \\
\operatorname{irt}_{i t} & =\lambda_{12}+\delta_{12} S_{i t}+\theta_{12} N_{i t}+\varepsilon_{i t}, \\
w_{i t} & =\lambda_{21}+\delta_{21} S_{i t}+\theta_{21} N_{i t}+\pi_{21} L_{i t}+\gamma_{i t}, \\
\operatorname{row}_{i t} & =\lambda_{22}+\delta_{22} S_{i t}+\theta_{22} N_{i t}+\mu_{i t},
\end{aligned}
$$

where $w$, irt, and row respectively represent the per capita income, the volume of intraregional trade, and the volume of trade with the rest of the world; $\lambda_{11}, \lambda_{12}, \lambda_{21}$, and $\lambda_{22}$ are constant parameters; $S$ is a vector of structural variables; $N$ is a vector of institutional and geographical variables; $L$ is a set of interactive terms; $\omega, \varepsilon, \gamma$, and $\mu$ are error terms; $i$ identifies a specific country; $t$ is the time subscript.

Structural variables include net overseas development assistance received (ODA) as a percentage of GDP, initial income per capita, investment, domestic inflation, broad money supply as a percentage of real GDP, the volume of intraregional trade as a percentage of GDP, and the volume of trade with the rest of the world as a percentage of GDP. Institutional and geographical variables are represented by a measure or an index for the corruption level, a regional dummy for UEMOA (the Union Économique et Monétaire Ouest Africaine (UEMOA) includes 8 member countries that share a single currency called the CFA franc: Benin, Burkina Faso, Côte d'Ivoire, Guinea-Bissau, Mali, Niger, Senegal, and Togo. They are also members of the ECOWAS) member
TAble 1: Net ODA per capita, from 1980 to 2009.

\begin{tabular}{lcc}
\hline Country & Average net ODA per capita (USD, 2000) & CV \\
\hline Benin & 54 & 0.2 \\
Burkina Faso & 58 & 0.14 \\
Cape Verde & 400 & 0.22 \\
Côte d'Ivoire & 48 & 0.65 \\
Gambia, The & 107 & 0.63 \\
Ghana & 47 & 0.27 \\
Guinea & 53 & 0.4 \\
Guinea-Bissau & 133 & 0.4 \\
Mali & 25 & 0.68 \\
Niger & 75 & 0.33 \\
Nigeria & 5 & 0.33 \\
Senegal & 86 & 0.63 \\
Sierra Leone & 200 & 0.29 \\
Togo & 54 & 0.33 \\
\hline
\end{tabular}

Source: World Bank [10]. CV: coefficient of variation.

countries and a war dummy. The set of interactive terms controls for the marginal effects of aid, on the one hand, and the interaction of aid with corruption level, on the other hand.

3.1. Per Capita Income Specifications. Equations (1) and (3) follow a neoclassical growth model specification. A lemma utilized in this investigation is that economic growth results from changes in aggregate output. Accordingly, the determinants of economic growth cannot be overlooked in the identification of factors that lead to changes in per capita output. In other words, we argue that determinants of economic growth are legitimate candidates in the ensemble of factors that may affect output per capita.

For many developing countries in Africa, foreign aid is a major source of revenue for governments. Evidence in these countries suggests that revenue collection efforts are either highly inefficient. This further increases the reliance of these countries on foreign sources of revenue. Political instability along with weak institutions adds to the poor macroeconomic environment that stifles foreign investment. Foreign aid has thus become a vital source of revenue to support needed governments' expenditures. Quazi [6] and Burnside and Dollar [2] consider aid as a determinant of output growth. Following in their lines of argument, aid is selected in this study as an important determinant of fluctuations in per capita income. On the other hand, the authors underscore the reverse causation problem that is likely to exist between the level of income and aid. Endogeneity may indeed result from the fact that aid allocations to a given country could be driven by this country's level of income. This aspect of the aid-growth equation - which is discussed by Hansen and Tarp [11] as well-is addressed in this paper. However, it is noteworthy to remark that there have been many cases where bilateral aid has been extended based solely upon the donor's strategic and/or geopolitical interests, irrespective of the recipient country's income level. Oftentimes, the same bilateral donors act as powerbrokers in international financial institutions to secure 
aid for their "protégés" among developing countries. For instance, Mobutu, the former dictator and ruler of ex-Zaire (1965-1997), secured a total loan package worth US\$274 million from the World Bank and the IMF shortly following a "successful" visit to the White House in 1989 [12, page 4]. Similarly, for decades France has not shied away from lobbying and exerting its influence in the international financial sphere to help secure loans to former colonies with pro-French rulers or dictators. This has come in addition to the bilateral aid she allocates on a regular basis. Accordingly and for all practical purposes, this work considers aid to be exogenous. There is also no empirical evidence-from our dataset and models - that our findings are compromised by a possible endogeneity problem involving the level of income and foreign aid. To check whether potential endogeneity problems corrupt our results from baseline models, they were run with aid being lagged one and two periods successively. Results do not alter our findings as the lagged covariates remain insignificant, while the significances and magnitudes of other variables are not noticeably affected. These covariates were consequently dropped from the final forms of models exposed here.

Initial income per capita is introduced to account for the difference in development levels within the 15-member strong regional association at the beginning of the study period. In addition, it addresses the convergence theory which is described in the development economics literature [13]. Investment (in physical capital) is included in the study to capture capital formation in the ECOWAS. Capital formation is an instrumental factor in the neoclassical growth model. A variety of empirical studies in the literature have established that investment is a key driver of economic growth as well as changes in per capita output $[14,15]$ (See also Hadiwibowo [16]). Domestic inflation remains an important factor that affects economic growth. Fluctuations in the price level have been known through the literature to be a determinant of economic growth $[17,18]$.

In ECOWAS member countries, there have been many instances of corruption and displays of poor governance since the years of independence. Embezzlements along with a weak prevalence of the rule of law have reached such a level that economic growth could be affected. It thus appears essential in any study involving these countries to account for these problems. Intraregional trade, that is, intra-ECOWAS trade, is included as it is one of the two variables that are central to this investigation.

ODA squared is included in our baseline models to account for the marginal effects of ODA on a country's economic growth, while an interaction term of corruption and ODA is also considered. It is noteworthy that rampant corruption could affect the effectiveness of ODA as well (see, e.g., Burnside and Dollar [2], among others).

Monetary policy is proxied by a measure of broad money as a percentage of GDP. It is lagged one period to isolate the noncontemporaneous impacts of monetary policy on economic growth. At last, corruption perception index (CPI) accuracy and membership into the CFA franc zone are captured by two separate bivariates. The former is introduced to assess whether the proxies for the missing corruption perception indexes in some years are accurately measuring the true, but unavailable, CPI. The latter is controlling for the fact that 8 ECOWAS member countries share a common currency called the CFA franc.

3.2. Trade Specifications. Equations (2) and (4) capture the relationships between irt, row, and their respective determinants. Both equations share the same basic determinants.

By drawing upon diverse studies in the literature, our model identifies 8 covariates for the ECOWAS. These studies include Hughes [19], Ilorah [4], Yang and Gupta [20], and Frankel and Romer [7], among others. Trade in general, whether intraregional or not, is expected to increase along with per capita income of a given country. Similar to (1) and (3), the broad money as a percentage of GDP is introduced to control for the impacts of monetary policy. As a matter of fact, monetary policy can affect trade through two distinct channels.

On the one hand, the direct channel is achieved as a result of a change in interest rate that can affect the money market. Indeed, in developing countries, farmers and exporters solicit banking institutions for advances in the form of (shortterm) loans to finance harvest and other related costs-such as transportation and stocking costs. For instance, in Côte d'Ivoire and Ghana - two large exporters of coffee and cocoa in Africa-this is a practice that is widely utilized by farmers and corporations in charge of collecting and conveying these crops to seaports. On the other hand, through the indirect channel, monetary policy does impact the economy as a whole, which in turn influence inflows and outflows of goods in a country.

Furthermore, domestic inflation is identified and controlled for in (2) and (4). Indeed, domestic inflation can be driven by both real factors as well as nominal factors, namely, an expansionary monetary policy. The prevalence of corruption can impede flows of goods in and out of the country as administrative red tapes are raised. At last, the existence of a monetary union-the UEMOA-and social instability and/or the outbreak of war are addressed with two separate dummy variables. In accordance with Gourdon [21], we introduce population as a covariate to address scale effects in the ECOWAS. Indeed, the distribution of populations in this regional group presents notable discrepancies from the most populous countries-Nigeria (169 million), Ghana (24 million), and Côte d'Ivoire (22 million) — to the least populous ones_Gambia (1.8 million), Guinea-Bissau (1.7 million), and Cape Verde (0.6 million) (ECOWAS total population is roughly 300 million strong. All populations are estimates, and they are current as of 2011. Source: World Bank). Furthermore, the marginal effects of the size of population are captured with population squared as a covariate.

In light of the specifications aforediscussed, our baseline models take the following forms:

$$
\begin{aligned}
w_{i t}= & \alpha_{1,1}+\alpha_{1,2}(\text { aid })_{i t}+\alpha_{1,3} \ln (\text { init_inc })_{i t} \\
& +\alpha_{1,4}(\text { inflation })_{i t}+\alpha_{1,5}(\text { corruption })_{i t} \\
& +\alpha_{1,6}(\text { corruption } * \text { aid })_{i t}+\alpha_{1,7}(\text { aid } * \text { aid })_{i t}
\end{aligned}
$$




$$
\begin{aligned}
& +\alpha_{1,8}(\text { investment })_{i t}+\alpha_{1,9}(\text { irt })_{i t} \\
& +\alpha_{1,10}(\text { broad_money })_{i t}+\alpha_{1,11}(\text { trend })_{i t} \\
& +\alpha_{1,12}(\text { war })_{i t}+\alpha_{1,13}(\text { UEMOA })_{i t} \\
& +\alpha_{1,14}(\text { corruption_1994 })_{i t}+\omega_{i t}
\end{aligned}
$$

$$
\begin{aligned}
\operatorname{irt}_{i t}= & \beta_{1,1}+\beta_{1,2} \ln \left(\text { income }_{\mathrm{pc}}\right)_{i t}+\beta_{1,3}(\text { broad_money })_{i t} \\
& +\beta_{1,4}(\text { inflation })_{i t}+\beta_{1,5} \ln (\text { population }) \\
& +\beta_{1,6} \ln (\text { population })^{2}+\beta_{1,7}(\text { war })_{i t} \\
& +\beta_{1,8}(\mathrm{UEMOA})_{i t}+\beta_{1,9}\left(\text { corruption } \_1994\right)_{i t}+\varepsilon_{i t},
\end{aligned}
$$

$$
\begin{aligned}
w_{i t}= & \alpha_{2,1}+\alpha_{2,2}(\text { aid })_{i t}+\alpha_{2,3} \ln (\text { init_inc })_{i t} \\
& +\alpha_{2,4}(\text { inflation })_{i t}+\alpha_{2,5}(\text { corruption })_{i t} \\
& +\alpha_{2,6}(\text { corruption } * \text { aid })_{i t}+\alpha_{2,7}(\text { aid } * \text { aid })_{i t} \\
& +\alpha_{2,8}(\text { investment })_{i t}+\alpha_{2,9}(\text { row })_{i t} \\
& +\alpha_{2,10}(\text { broad_money })_{i t}+\alpha_{2,11}(\text { trend })_{i t} \\
& +\alpha_{2,12}(\text { war })_{i t}+\alpha_{2,13}(\text { UEMOA })_{i t} \\
& +\alpha_{2,14}(\text { corruption_1994 })_{i t}+\gamma_{i t},
\end{aligned}
$$

$$
\begin{aligned}
\operatorname{row}_{i t}= & \beta_{2,1}+\beta_{2,2} \ln (\text { inc_pc })_{i t}+\beta_{2,3}(\text { broad_money })_{i t} \\
& +\beta_{2,4}(\text { inflation })_{i t}+\beta_{2,5} \ln (\text { population }) \\
& +\beta_{2,6} \ln (\text { population })^{2}+\beta_{2,7}(\text { war })_{i t} \\
& +\beta_{2,8}(\mathrm{UEMOA})_{i t}+\beta_{2,9}(\text { corruption_1994 })_{i t} \\
& +\mu_{i t}
\end{aligned}
$$

where init_inc and inc_pc represent initial income and per capita income, respectively. War is a dummy variable that captures social instability and/or the outbreak of a war that may perturb economic activities_-including trade activities, and corruption_1994 is another dummy variable meant to capture the accuracy of proxies used for missing CPI values, as noted above.

We use one instrumental variable in each baseline model. The set of variables used to construct this instrumental variable comprises income per capita, broad money as a share of GDP, domestic inflation, a measure of corruption (corruption perception index), corruption_1994, population, population squared, and the UEMOA and war dummies.

In bmod1 (5) and (6) are overidentified considering that they exclude more than 1 variable each. Considering that there are 2 endogenous variables in each baseline model, an equation is overidentified if the number of variable(s) excluded is greater than 1 (that is, 2-1). Specifically, (5) and
(7) exclude 3 variables each, while (6) and (8) exclude 6 variables each. The same reasoning applies to (7) and (8), in bmod2, which are found to be overidentified as well. We have met identification conditions making, therefore, the TSLS an appropriate and potent estimation technique in the present study (pending the proof that there is a simultaneity problem. This is addressed later on).

The empirical methodology follows 3 distinct steps that involve 3 distinct variants for each baseline model. Considering the fact that $\operatorname{irt}_{i t}$ and $\omega_{i t}$ in $b \bmod 1$-likewise for row $_{i t}$ and $\gamma_{i t}$, in bmod2-are likely to be correlated, a simple ordinary least squares (OLSs) method will produce estimates that are biased, inconsistent, and inefficient. This will be an indication of the existence of a simultaneity problem. In order to correct for these problems and derive stronger estimates, we have recourse to a more powerful technique, the two-stage least squares (TSLS, hereafter) along with instrumental variables.

The first step applies the Hausman specification test [22] to check for the existence, or not, of any simultaneity problem in the baseline models. These results are reported in Table 2. In the second step, we estimate different variants of our baseline models using the TSLS approach. These results are presented in Tables 3 and 4. Following these findings, we assess the robustness of our results in a third step by modifying the baseline models to account for both fixed and random effects.

It is indeed possible that country-specific characteristics could have been missed by our preliminary estimations. Moreover, we assess how random sampling from a much broader pool of developing countries in Africa does affect our estimates (the fixed and random effects specifications are not presented here as they have been largely discussed in the literature. Accordingly, they are succinctly surveyed in the Appendix for the reader).

3.3. Data Description. The dataset ranges from 1980 to 2009 and comprises a panel of 14 member nations of the Economic Community of West African States (ECOWAS). Liberia was dropped from the final pool of member countries due to data limitations.

The availability of CPI was scattered and discontinued before 1994 for certain countries. To produce a balanced pool, estimations for missing values are computed using available CPIs along with information derived from official documents and widely publicized news media reports. At last, a dummy capturing the accuracy of these estimates and their impacts on results is introduced to further assess the strength of our findings. Definitions and sources of variables are summarized in Table 9.

\section{Results and Implications}

Results from Table 2 reveal that there are persistent endogeneity problems in the different variants of bmod1 and bmod2. For the former model, the Hausman test detects the presence of endogeneity at the 5 percent significance level for variants I, II, and III. As far as the latter model is concerned, it appears that endogeneity exists in variants II and III at 
TABLE 2: Hausman tests of endogeneity.

\begin{tabular}{lccc}
\hline$b \bmod 1$ & Coefficient of residuals $\hat{\chi}_{i t}$ & $P$ values & Ho: nonexistence of endogeneity \\
\hline I & -0.512 & $0.023^{* *}$ & Reject \\
II & -0.314 & $0.021^{* *}$ & Reject \\
III & -0.326 & $0.042^{* *}$ & Reject \\
\hline bmod2 & Coefficient of residuals $\hat{\varphi}_{i t}$ & $P$ values & Ho: nonexistence of endogeneity \\
\hline I & -0.723 & $0.072^{*}$ & Reject \\
II & -0.625 & $0.006^{* * *}$ & Reject \\
III & -0.129 & $0.007^{* * *}$ & Reject \\
\hline
\end{tabular}

${ }^{* * *}$ Indicates significance at the 1 percent level.

** Indicates significance at the 5 percent level.

* Indicates significance at the 10 percent level.

TABle 3: Regression estimates of bmod1. Dependent variable: income per capita (in natural logarithm).

\begin{tabular}{|c|c|c|c|c|c|c|}
\hline \multirow{2}{*}{ Independent variables } & \multicolumn{2}{|c|}{ I } & \multicolumn{2}{|c|}{ II } & \multicolumn{2}{|c|}{ III } \\
\hline & OLS & TSLS & OLS & TSLS & OLS & TSLS \\
\hline \multirow[t]{2}{*}{ Aid } & $-0.012^{* * *}$ & $-0.014^{* * *}$ & $-0.006^{* * *}$ & $-0.009^{* * *}$ & $-0.007^{* * *}$ & $-0.008^{* * *}$ \\
\hline & $(2.59)$ & $(2.61)$ & $(3.12)$ & $(2.95)$ & $(3.01)$ & $(2.65)$ \\
\hline \multirow[t]{2}{*}{ Initial income } & $0.001^{* * *}$ & 0.0003 & $0.001^{* * *}$ & $-0.0007^{* * *}$ & $0.001^{* * *}$ & -0.0009 \\
\hline & $(3.15)$ & $(1.25)$ & $(3.11)$ & $(2.77)$ & $(2.9)$ & $(1.06)$ \\
\hline \multirow[t]{2}{*}{ Inflation } & -0.003 & -0.004 & $-0.001^{* * *}$ & $-0.001^{* * *}$ & $-0.001^{* *}$ & $-0.025^{* * *}$ \\
\hline & $(0.98)$ & $(1.32)$ & $(2.58)$ & $(2.69)$ & $(2.11)$ & $(3.01)$ \\
\hline \multirow[t]{2}{*}{ Corruption } & $0.116^{* * *}$ & $0.123^{*}$ & $0.161^{* *}$ & 0.027 & $0.166^{* * *}$ & $0.09^{* *}$ \\
\hline & $(3.22)$ & $(1.55)$ & $(2.01)$ & $(1.13)$ & $(3.02)$ & $(1.98)$ \\
\hline \multirow[t]{2}{*}{ Corruption $*$ aid } & $0.002^{* * *}$ & 0.001 & 0.0002 & $0.0002^{*}$ & 0.0007 & $0.0006^{*}$ \\
\hline & $(2.61)$ & $(1.25)$ & $(1.41)$ & $(1.74)$ & $(1.09)$ & $(1.65)$ \\
\hline \multirow[t]{2}{*}{ Aid $*$ aid } & $0.0004^{* * *}$ & $0.0005^{* * *}$ & $0.0004^{* * *}$ & $0.001^{* * *}$ & $0.0004^{* * *}$ & $0.001^{* * *}$ \\
\hline & $(2.99)$ & $(2.86)$ & (3.1) & $(2.97)$ & $(3.22)$ & $(3.72)$ \\
\hline \multirow[t]{2}{*}{ Investment } & 0.0001 & $-0.0004^{* * *}$ & $0.0004^{* * *}$ & $-0.0006^{* *}$ & 0.0003 & $0.0001^{* *}$ \\
\hline & $(0.56)$ & $(2.95)$ & $(4.21)$ & $(1.97)$ & $(1.47)$ & $(2.36)$ \\
\hline \multirow[t]{2}{*}{ Intra-ECOWAS trade } & -0.001 & 0.013 & $0.012^{* * *}$ & $0.025^{*}$ & $0.011^{* * *}$ & $0.028^{*}$ \\
\hline & $(1.55)$ & $(1.02)$ & $(3.89)$ & $(1.75)$ & $(4.32)$ & $(1.88)$ \\
\hline \multirow[t]{2}{*}{ Broad money supply } & $0.029^{* * *}$ & $0.001^{*}$ & $0.003^{* * *}$ & 0.001 & $0.003^{* * *}$ & 0.0001 \\
\hline & $(4.54)$ & $(1.79)$ & $(2.85)$ & $(1.26)$ & $(2.94)$ & $(1.56)$ \\
\hline \multirow[t]{2}{*}{ Trend } & $0.003^{* *}$ & $-0.013^{* *}$ & $0.002^{*}$ & -0.007 & $0.006^{* *}$ & 0.014 \\
\hline & $(1.98)$ & $(2.44)$ & $(1.78)$ & $(0.84)$ & $(1.97)$ & $(1.45)$ \\
\hline \multirow[t]{2}{*}{ War } & - & - & $-0.158^{*}$ & -0.031 & $-0.156^{*}$ & $-0.049^{*}$ \\
\hline & & & $(1.77)$ & $(1.13)$ & $(1.66)$ & $(1.71)$ \\
\hline \multirow[t]{2}{*}{ UEMOA } & - & - & $-0.186^{* * *}$ & -0.007 & $-0.187^{* * *}$ & $-0.336^{* *}$ \\
\hline & & & $(3.96)$ & $(0.78)$ & $(3.25)$ & $(1.97)$ \\
\hline \multirow[t]{2}{*}{ Corruption_1994 } & - & - & - & - & 0.066 & 0.786 \\
\hline & & & & & $(1.02)$ & $(1.41)$ \\
\hline \multirow[t]{2}{*}{$c$} & $4.921^{* * *}$ & $6.882^{* * *}$ & $4.919 * * *$ & $7.281^{* * *}$ & $4.84^{* * *}$ & $6.355^{* * *}$ \\
\hline & $(5.01)$ & $(3.25)$ & $(3.79)$ & $(5.02)$ & $(7.16)$ & $(7.01)$ \\
\hline Number of countries & 14 & 14 & 14 & 14 & 14 & 14 \\
\hline Observations & 419 & 419 & 419 & 419 & 419 & 419 \\
\hline Adjusted $R^{2}$ & 0.53 & 0.12 & 0.61 & 0.64 & 0.61 & 0.6 \\
\hline$F$ statistics & $116^{* * *}$ & $45^{* * *}$ & $56^{* * *}$ & $138^{* * *}$ & $211^{* * *}$ & $122 * * *$ \\
\hline
\end{tabular}

${ }^{* * *}$ Indicates significance at the 1 percent level.

** Indicates significance at the 5 percent level.

* Indicates significance at the 10 percent level.

$t$ statistics are in parenthesis. 
TABLE 4: Regression estimates of bmod2. Dependent variable: income per capita (in natural logarithm).

\begin{tabular}{|c|c|c|c|c|c|c|}
\hline \multirow{2}{*}{ Independent variables } & \multicolumn{2}{|c|}{ I } & \multicolumn{2}{|c|}{ II } & \multicolumn{2}{|c|}{ III } \\
\hline & OLS & TSLS & OLS & TSLS & OLS & TSLS \\
\hline \multirow[t]{2}{*}{ Aid } & $-0.016^{* * *}$ & $-0.012 * *$ & $-0.009^{* * *}$ & $-0.022^{* * *}$ & $-0.009^{* * *}$ & -0.014 \\
\hline & $(2.63)$ & $(2.15)$ & $(4.02)$ & $(5.13)$ & $(4.12)$ & $(1.61)$ \\
\hline \multirow[t]{2}{*}{ Initial income } & $0.002^{* * *}$ & 0.01 & $0.001^{* *}$ & $0.08^{* *}$ & $0.001^{* * *}$ & -0.007 \\
\hline & $(3.15)$ & $(0.16)$ & $(2.03)$ & $(2.17)$ & $(4.11)$ & $(1.52)$ \\
\hline \multirow[t]{2}{*}{ Inflation } & -0.4 & $-0.008^{* * *}$ & $-0.002^{* * *}$ & -0.0003 & $-0.002^{* * *}$ & -0.034 \\
\hline & $(0.97)$ & $(2.74)$ & $(4.19)$ & $(1.34)$ & $(3.48)$ & $(0.32)$ \\
\hline \multirow[t]{2}{*}{ Corruption } & $0.093^{* *}$ & -0.107 & $0.08^{* * *}$ & 0.091 & $0.101^{* * *}$ & $0.117^{* *}$ \\
\hline & $(1.97)$ & $(1.11)$ & $(2.81)$ & $(0.37)$ & $(2.67)$ & $(1.96)$ \\
\hline \multirow[t]{2}{*}{ Corruption $*$ aid } & $0.003 * * *$ & $0.002 * * *$ & 0.009 & $0.0006^{* *}$ & 0.002 & -0.003 \\
\hline & $(4.16)$ & $(3.05)$ & $(0.87)$ & $(2.08)$ & $(1.17)$ & $(1.42)$ \\
\hline \multirow[t]{2}{*}{ Aid $*$ aid } & $0.01^{* * *}$ & $-0.01^{* * *}$ & $-0.03 * * *$ & $-0.027 * * *$ & $-0.046^{* * *}$ & $-0.002 * *$ \\
\hline & $(3.02)$ & $(2.89)$ & $(2.93)$ & $(3.74)$ & (3.12) & $(3.75)$ \\
\hline \multirow[t]{2}{*}{ Investment } & -0.07 & $-0.027^{*}$ & $-0.01^{* *}$ & $-0.001^{* * *}$ & -0.051 & -0.04 \\
\hline & $(0.93)$ & (1.89) & (1.99) & $(3.36)$ & $(1.43)$ & $(1.60)$ \\
\hline \multirow[t]{2}{*}{ World trade } & $0.015^{* * *}$ & $0.004^{*}$ & $0.003^{* * *}$ & $0.035^{*}$ & 0.022 & $0.011^{*}$ \\
\hline & $(2.62)$ & $(1.77)$ & $(4.51)$ & $(1.73)$ & $(0.85)$ & $(1.78)$ \\
\hline \multirow[t]{2}{*}{ Broad money supply } & $0.002 * * *$ & 0.08 & $0.002^{* * *}$ & 0.012 & $0.02^{* * *}$ & -0.004 \\
\hline & $(3.36)$ & (1.14) & $(3.25)$ & $(1.44)$ & $(2.78)$ & $(1.47)$ \\
\hline \multirow[t]{2}{*}{ Trend } & $-0.003^{* *}$ & -0.004 & $-0.002^{* *}$ & 0.013 & -0.002 & 0.013 \\
\hline & $(3.23)$ & $(0.32)$ & (1.98) & $(1.37)$ & (1.19) & $(1.03)$ \\
\hline \multirow[t]{2}{*}{ War } & - & - & $-0.141^{* * *}$ & 0.083 & $-0.140^{* * *}$ & 0.6 \\
\hline & & & (3.39) & $(1.12)$ & $(2.88)$ & $(1.37)$ \\
\hline \multirow[t]{2}{*}{ UEMOA } & - & - & $-0.217^{* * *}$ & 0.754 & $-0.23^{* *}$ & -0.851 \\
\hline & & & $(3.01)$ & $(0.19)$ & $(1.97)$ & $(1.26)$ \\
\hline \multirow[t]{2}{*}{ Corruption_1994 } & - & - & - & - & 0.016 & 1.043 \\
\hline & & & & & $(1.37)$ & $(1.52)$ \\
\hline \multirow[t]{2}{*}{$c$} & $4.932 * * *$ & $7.037^{* * *}$ & $4.931^{* * *}$ & $9.489^{* * *}$ & $4.913^{* *}$ & $4.717^{*}$ \\
\hline & $(5.52)$ & $(6.32)$ & $(4.25)$ & $(6.41)$ & $(4.92)$ & $(1.72)$ \\
\hline Number of countries & 14 & 14 & 14 & 14 & 14 & 14 \\
\hline Observations & 419 & 419 & 419 & 419 & 419 & 419 \\
\hline Adjusted $R^{2}$ & 0.51 & 0.36 & 0.54 & 0.72 & 0.84 & 0.70 \\
\hline$F$ statistics & $181^{* * *}$ & $130^{* * *}$ & $194^{* * *}$ & $124^{* * *}$ & $178^{* * *}$ & $155^{* * *}$ \\
\hline
\end{tabular}

*** Indicates significance at the 1 percent level.

** Indicates significance at the 5 percent level.

* Indicates significance at the 10 percent level.

$t$ statistics are in parenthesis.

the 1 percent significance level. This level of significance for endogeneity increases to 10 percent for variant I. The use of TSLS is hence justified, and it is unlikely to generate spurious results in our empirical analysis. To provide a comprehensive understanding of the implications of findings in this study, we report in Tables 3 and 4 both the OLS and TSLS estimates pertaining to each variant of bmodl and bmod2. Tables 58 display estimates using the TSLS only as we are assessing the robustness of our preliminary findings. To contain the overall length of this work and in furtherance of conciseness, only the results of final stages are presented. All other results (first stages with $\operatorname{irt}_{i t}$ and row $_{i t}$ ) are available from the author upon request.

Overall, 3 variants of (1) and (2), are assessed in the first step. As a matter of fact, variant I considers the baseline model without any dummy. We improve variant I, via variants II and III, by accounting for the existence of (i) the UEMOA within the ECOWAS and (ii) potential disturbances to economic activities emanating from noneconomic factors. We believe that this move is warranted in this study, for this region has been prone to violent civil unrests - including wars - in the timespan of our dataset. These 3 variants consistently indicate a significant and negative relationship between aid to developing countries of ECOWAS and expansion in per capita income. For instance, the first variant of bmodl in Table 3 suggests that a 1 percentage point increase in net aid as a share of GDP generates a decrease in per capita income by about 1.4 percent, while this decrease is about 0.9 and 0.8 percent for variants II and III, respectively. On the contrary, intraECOWAS trade as a share of GDP remains significant at the 10 percent level, and it positively affects expansion of 
TABLE 5: Regression estimates: fixed effects specifications of bmod1. Dependent variable: income per capita (in natural logarithm).

\begin{tabular}{|c|c|c|c|c|c|c|}
\hline \multirow{2}{*}{ Independent variables } & \multicolumn{2}{|c|}{ I } & \multicolumn{2}{|c|}{ III } & \multicolumn{2}{|c|}{ III } \\
\hline & WRSE & PCSE & WRSE & PCSE & WRSE & PCSE \\
\hline Aid & $\begin{array}{c}-0.049^{* * *} \\
(4.23)\end{array}$ & $\begin{array}{c}-0.049^{* * *} \\
(4.23)\end{array}$ & $\begin{array}{c}-0.042^{* * *} \\
(4.93)\end{array}$ & $\begin{array}{c}-0.042^{* * *} \\
(4.93)\end{array}$ & $\begin{array}{c}-0.047^{* * *} \\
(6.12)\end{array}$ & $\begin{array}{c}-0.047^{* *} \\
(6.13)\end{array}$ \\
\hline Initial income & $\begin{array}{c}0.375^{* * *} \\
\quad(5.02)\end{array}$ & $\begin{array}{c}0.375^{* * *} \\
\quad(5.02)\end{array}$ & $\begin{array}{c}0.357^{* * *} \\
(4.23)\end{array}$ & $\begin{array}{c}0.357^{* * *} \\
(4.22)\end{array}$ & $\begin{array}{c}0.352 * * * \\
\quad(5.42)\end{array}$ & $\begin{array}{c}0.352^{* * *} \\
(5.42)\end{array}$ \\
\hline Inflation & $\begin{array}{c}-0.005^{* *} \\
(2.52)\end{array}$ & $\begin{array}{c}-0.005^{* * *} \\
(2.59)\end{array}$ & $\begin{array}{c}-0.007^{* * *} \\
(6.33)\end{array}$ & $\begin{array}{c}-0.007^{* * *} \\
(6.33)\end{array}$ & $\begin{array}{c}-0.02^{* * *} \\
(5.37)\end{array}$ & $\begin{array}{c}-0.02^{* * *} \\
(5.37)\end{array}$ \\
\hline Corruption & $\begin{array}{c}0.247^{* *} \\
(2.55)\end{array}$ & $\begin{array}{c}0.247^{* * *} \\
(2.58)\end{array}$ & $\begin{array}{c}0.254^{* * *} \\
(4.14)\end{array}$ & $\begin{array}{c}0.254^{* * *} \\
(4.14)\end{array}$ & $\begin{array}{c}0.256^{* * *} \\
(4.75)\end{array}$ & $\begin{array}{c}0.256^{* * *} \\
(4.75)\end{array}$ \\
\hline Corruption $*$ aid & $\begin{array}{l}0.001 \\
(1.02)\end{array}$ & $\begin{array}{l}0.001 \\
(1.02)\end{array}$ & $\begin{array}{c}-0.004^{* * *} \\
(2.94)\end{array}$ & $\begin{array}{c}-0.004^{* * *} \\
(2.94)\end{array}$ & $\begin{array}{c}-0.005^{* * *} \\
(3.41)\end{array}$ & $\begin{array}{c}-0.005^{* * *} \\
(3.41)\end{array}$ \\
\hline Aid $*$ aid & $\begin{array}{c}-0.014^{* * *} \\
(6.02)\end{array}$ & $\begin{array}{c}-0.014^{* * *} \\
(6.02)\end{array}$ & $\begin{array}{c}-0.008^{* *} \\
(2.0)\end{array}$ & $\begin{array}{c}-0.008^{* *} \\
(2.0)\end{array}$ & $\begin{array}{c}-0.007^{* *} \\
(1.98)\end{array}$ & $\begin{array}{c}-0.007^{*} \\
(1.65)\end{array}$ \\
\hline Investment & $\begin{array}{c}0.03 \\
(1.02)\end{array}$ & $\begin{array}{c}0.03^{* *} \\
(2.14)\end{array}$ & $\begin{array}{c}0.04^{* *} \\
(1.97)\end{array}$ & $\begin{array}{c}0.04^{* *} \\
(1.97)\end{array}$ & $\begin{array}{c}0.05^{* *} \\
(2.01)\end{array}$ & $\begin{array}{c}0.05^{* *} \\
(2.02)\end{array}$ \\
\hline Intra-ECOWAS trade & $\begin{array}{l}0.006 \\
(1.61)\end{array}$ & $\begin{array}{c}0.006^{* * *} \\
(2.59)\end{array}$ & $\begin{array}{c}0.035^{* *} \\
(2.49)\end{array}$ & $\begin{array}{c}0.035^{* *} \\
(2.49)\end{array}$ & $\begin{array}{c}0.052^{*} \\
(1.75)\end{array}$ & $\begin{array}{c}0.052^{*} \\
(1.75)\end{array}$ \\
\hline Broad money supply & $\begin{array}{c}0.003^{* * *} \\
(6.3)\end{array}$ & $\begin{array}{c}0.003^{* *} \\
(1.96)\end{array}$ & $\begin{array}{c}0.002^{* * *} \\
(2.59)\end{array}$ & $\begin{array}{c}0.002^{* * *} \\
(4.61)\end{array}$ & $\begin{array}{l}0.001 \\
(1.13)\end{array}$ & $\begin{array}{l}0.001 \\
(1.13)\end{array}$ \\
\hline Trend & $\begin{array}{c}-0.004 \\
(1.44)\end{array}$ & $\begin{array}{c}-0.004 \\
(1.44)\end{array}$ & $\begin{array}{c}-0.005^{* *} \\
(1.99)\end{array}$ & $\begin{array}{c}-0.005^{* *} \\
(1.99)\end{array}$ & $\begin{array}{l}0.003 \\
(1.63)\end{array}$ & $\begin{array}{l}0.003 \\
(1.63)\end{array}$ \\
\hline War & - & - & $\begin{array}{l}0.013 \\
(0.63)\end{array}$ & $\begin{array}{l}0.013 \\
(0.63)\end{array}$ & $\begin{array}{l}0.016 \\
(0.98)\end{array}$ & $\begin{array}{l}0.016 \\
(0.98)\end{array}$ \\
\hline UEMOA & - & - & $\begin{array}{c}-0.185^{* * *} \\
(3.17)\end{array}$ & $\begin{array}{c}-0.185^{* * *} \\
(3.17)\end{array}$ & $\begin{array}{c}-0.353^{* * *} \\
(2.57)\end{array}$ & $\begin{array}{c}-0.353^{* *} \\
(2.52)\end{array}$ \\
\hline Corruption_1994 & - & 一 & - & - & $\begin{array}{c}0.301^{*} \\
(1.68)\end{array}$ & $\begin{array}{c}0.301^{*} \\
(1.68)\end{array}$ \\
\hline$c$ & $\begin{array}{c}6.782 * * * \\
(3.73)\end{array}$ & $\begin{array}{c}6.782^{* * *} \\
(3.73)\end{array}$ & $\begin{array}{c}7.073^{* * *} \\
(4.58)\end{array}$ & $\begin{array}{c}7.073^{* * *} \\
(4.58)\end{array}$ & $\begin{array}{c}6.221^{* * *} \\
(3.01)\end{array}$ & $\begin{array}{c}6.221^{* * *} \\
(3.01)\end{array}$ \\
\hline Number of countries & 14 & 14 & 14 & 14 & 14 & 14 \\
\hline Observations & 419 & 419 & 419 & 419 & 419 & 419 \\
\hline Adjusted $R^{2}$ & 0.61 & 0.61 & 0.65 & 0.65 & 0.61 & 0.61 \\
\hline$F$ statistics & $298^{* * *}$ & $298^{* * *}$ & $231^{* * *}$ & $231^{* * *}$ & $175^{* * *}$ & $175^{* * *}$ \\
\hline
\end{tabular}

*** Indicates significance at the 1 percent level.

$* *$ Indicates significance at the 5 percent level.

* Indicates significance at the 10 percent level.

$t$ statistics are in parenthesis.

per capita income in member countries of the ECOWAS in variants II and III. The OLS methods in Variant I indicate a negative relationship, yet it is insignificant at any acceptable level (i.e., $1 \%, 5 \%$ or $10 \%$ ). Indeed, one observes that there is an increase in per capita income by roughly 2.5 and 2.8 percent following every percentage point increase in the share of intra-ECOWAS trade in GDP for variants II and III, respectively.

On the other hand, empirical results signal that corruption (based on the Corruption Perception Index (CPI) published by Transparency International, the higher the index the "cleaner", or less corrupt, the country is) is a significant determinant of changes in per capita income, and it is correctly signed in all variants. That is less "clean" countries experience a decline in the growth of per capita income, creating thereby the conditions for a decrease-or stagnation, at best-in the standard of living. It appears that the percentage gains in per capita income are, on average, in the double digits or close, as the country gets "cleaner," or alleviates the prevalence of corruption. Additionally, the interaction term between net aid (as a share of GDP) and corruption shows a positive sign and remains significant. The main implication of this finding is that aid props up per capita income once corruption is headed off. This outcome also corroborates evidence found in the literature suggesting that aid is more effective in developing countries where good policies are implemented [2].

Our argument, stating that ECOWAS member countries should focus on developing intraregional trade, hinges on two premises. First, it is well known and documented that corruption has been out of control in these developing countries for decades. In such an environment marred with 
TABle 6: Regression estimates: fixed effects specifications of bmod2. Dependent variable: income per capita (in natural logarithm).

\begin{tabular}{|c|c|c|c|c|c|c|}
\hline \multirow{2}{*}{ Independent variables } & \multicolumn{2}{|c|}{ I } & \multicolumn{2}{|c|}{ III } & \multicolumn{2}{|c|}{ III } \\
\hline & WRSE & PCSE & WRSE & PCSE & WRSE & PCSE \\
\hline \multirow[t]{2}{*}{ Aid } & $-0.018^{* * *}$ & $-0.018^{* * *}$ & 0.011 & 0.011 & -0.029 & -0.029 \\
\hline & $(5.6)$ & $(5.6)$ & $(1.36)$ & $(1.36)$ & $(1.42)$ & $(1.42)$ \\
\hline \multirow[t]{2}{*}{ Initial income } & $0.72 * * *$ & $0.72 * * *$ & $0.725^{* * *}$ & $0.725^{* * *}$ & $0.724^{* * *}$ & $0.724^{* * *}$ \\
\hline & $(4.52)$ & $(4.52)$ & $(4.43)$ & $(4.43)$ & $(5.72)$ & $(5.72)$ \\
\hline \multirow[t]{2}{*}{ Inflation } & 0.003 & 0.003 & -0.003 & -0.003 & -0.004 & -0.004 \\
\hline & $(1.33)$ & $(1.33)$ & $(0.25)$ & $(0.25)$ & $(0.73)$ & $(0.73)$ \\
\hline Corruption & $\begin{array}{c}0.171^{* * *} \\
(3.11)\end{array}$ & $\begin{array}{c}0.171^{* * *} \\
(3.12)\end{array}$ & $\begin{array}{c}0.257^{* * *} \\
(4.07)\end{array}$ & $\begin{array}{c}0.257^{* * *} \\
(4.07)\end{array}$ & $\begin{array}{c}0.259^{* * *} \\
(3.63)\end{array}$ & $\begin{array}{c}0.259^{* * *} \\
(3.63)\end{array}$ \\
\hline \multirow[t]{2}{*}{ Corruption $*$ aid } & 0.008 & 0.008 & $-0.001^{* * *}$ & $-0.001^{* * *}$ & $-0.001^{* *}$ & $-0.001^{*}$ \\
\hline & $(1.55)$ & $(1.55)$ & $(3.74)$ & $(3.74)$ & (1.99) & $(1.94)$ \\
\hline \multirow[t]{2}{*}{ Aid $*$ aid } & $-0.015^{* * *}$ & $-0.015^{* * *}$ & $-0.013^{*}$ & $-0.013^{*}$ & $-0.004^{*}$ & $-0.004^{*}$ \\
\hline & $(5.14)$ & $(5.14)$ & $(1.76)$ & $(1.76)$ & $(1.82)$ & $(1.82)$ \\
\hline \multirow[t]{2}{*}{ Investment } & $0.01^{* * *}$ & $0.01^{* * *}$ & $0.06^{* * *}$ & $0.06^{* * *}$ & 0.059 & 0.059 \\
\hline & $(4.61)$ & $(4.61)$ & $(3.53)$ & $(3.53)$ & $(1.03)$ & $(1.03)$ \\
\hline \multirow[t]{2}{*}{ World trade } & 0.04 & 0.04 & $0.032 *$ & $0.032 *$ & $0.043^{*}$ & $0.043^{*}$ \\
\hline & $(1.16)$ & $(1.16)$ & $(1.73)$ & $(1.73)$ & $(1.77)$ & $(1.77)$ \\
\hline \multirow[t]{2}{*}{ Broad money supply } & $0.002 * * *$ & $0.002^{* * *}$ & $0.001^{* * *}$ & $0.001^{* * *}$ & $0.001^{* *}$ & $0.001^{* * *}$ \\
\hline & $(4.45)$ & $(4.45)$ & $(4.53)$ & $(4.53)$ & $(2.51)$ & $(2.59)$ \\
\hline \multirow[t]{2}{*}{ Trend } & $-0.001^{*}$ & $-0.001^{*}$ & $-0.002^{* * *}$ & $-0.002^{* * *}$ & -0.001 & -0.001 \\
\hline & $(1.68)$ & $(1.68)$ & $(3.47)$ & $(3.47)$ & $(1.52)$ & $(1.52)$ \\
\hline \multirow[t]{2}{*}{ War } & - & - & $-0.109^{* * *}$ & $-0.109^{* * *}$ & $-0.109^{* * *}$ & $-0.109^{* * *}$ \\
\hline & & & $(4.01)$ & $(4.01)$ & $(4.56)$ & $(4.56)$ \\
\hline \multirow[t]{2}{*}{ UEMOA } & - & - & $-0.198^{* * *}$ & $-0.198^{* * *}$ & $-0.200^{* * *}$ & $-0.200^{* * *}$ \\
\hline & & & $(2.86)$ & $(2.86)$ & $(3.02)$ & $(3.02)$ \\
\hline \multirow[t]{2}{*}{ Corruption_1994 } & - & - & - & - & 0.018 & 0.018 \\
\hline & & & & & $(1.25)$ & $(1.25)$ \\
\hline \multirow[t]{2}{*}{$c$} & $1.098^{* * *}$ & $1.098^{* * *}$ & 0.999 & 0.999 & $0.985^{* * *}$ & $0.985^{* * *}$ \\
\hline & $(3.12)$ & $(3.12)$ & $(1.03)$ & $(1.03)$ & $(4.51)$ & $(4.51)$ \\
\hline Number of countries & 14 & 14 & 14 & 14 & 14 & 14 \\
\hline Observations & 419 & 419 & 419 & 419 & 419 & 419 \\
\hline Adjusted $R^{2}$ & 0.79 & 0.79 & 0.80 & 0.80 & 0.80 & 0.80 \\
\hline$F$ statistics & $359^{* * *}$ & $359^{* * *}$ & $331^{* * *}$ & $331^{* * *}$ & $304^{* * *}$ & $304^{* * *}$ \\
\hline
\end{tabular}

*** Indicates significance at the 1 percent level.

$* *$ Indicates significance at the 5 percent level.

* Indicates significance at the 10 percent level.

$t$ statistics are in parenthesis.

corruption, the implementation of good policies becomes unachievable, which in turn renders any foreign aid not only ineffective, but in practice inhibitive to growth in income per capita, as implied by the study. Second, even in an environment cleansed of corruption, the impact of aid remains negligible compared to intraregional trade. In the best scenario, the increase in per capita income is 0.06 percent following a percentage point increase in the volume of intraregional trade as a share of GDP after accounting for corruption, while one reads 2.8 percent for intraregional trade in the same conditions (Table 3 , variant III).

Moreover, the marginal effect of foreign aid on per capita income growth is positive but inconsequential although it remains significant. The CFA franc zone dummy proves significant with a negative sign suggesting that countries belonging to the UEMOA will on average experience a slower growth in per capita income compared to non-UEMOA member countries in the ECOWAS. Such a finding points to the fact that the CFA franc may constitute an impediment that prevents UEMOA countries to expand their per capita income and economies to their fullest potential. Since the late 1990s, many scholars_-including Agbohou [24] - have been questioning the continued existence of the CFA franc which is not reflective of the current economic fundamentals of UEMOA countries. It is worth pointing out that this currency was created in 1945 (preindependence era) by former colonial power-France-to essentially accommodate French economic interests rather than those of UEMOA member states, which it was destined to. Until this day, most of these precolonial monetary arrangements do exist 
TABLE 7: Regression estimates: random effects specifications of bmod1. Dependent variable: income per capita (in natural logarithm).

\begin{tabular}{|c|c|c|c|c|c|c|}
\hline \multirow{2}{*}{ Independent variables } & \multicolumn{2}{|c|}{ I } & \multicolumn{2}{|c|}{ III } & \multicolumn{2}{|c|}{ III } \\
\hline & WRSE & PCSE & WRSE & PCSE & WRSE & PCSE \\
\hline \multirow[t]{2}{*}{ Aid } & $-0.031 * * *$ & $-0.031^{* * *}$ & -0.008 & -0.008 & 0.024 & 0.024 \\
\hline & $(5.05)$ & $(5.05)$ & $(1.63)$ & $(1.63)$ & $(1.59)$ & $(1.59)$ \\
\hline \multirow[t]{2}{*}{ Initial income } & -0.19 & -0.19 & $0.969^{* * *}$ & $0.969^{* * *}$ & $1.129^{*}$ & $1.129^{*}$ \\
\hline & $(1.41)$ & $(1.41)$ & $(3.36)$ & $(3.36)$ & $(1.85)$ & $(1.85)$ \\
\hline \multirow[t]{2}{*}{ Inflation } & $-0.012 * * *$ & $-0.012^{* * *}$ & $0.006^{* *}$ & $0.006^{* *}$ & 0.003 & 0.003 \\
\hline & $(3.54)$ & $(3.54)$ & $(1.97)$ & $(1.97)$ & $(1.12)$ & $(1.12)$ \\
\hline \multirow[t]{2}{*}{ Corruption } & -0.005 & -0.005 & $0.029^{* *}$ & $0.029^{* * *}$ & 0.408 & 0.408 \\
\hline & $(0.65)$ & $(0.65)$ & $(2.54)$ & $(2.58)$ & $(0.51)$ & $(0.51)$ \\
\hline \multirow[t]{2}{*}{ Corruption $*$ aid } & $0.002 * * *$ & $0.002 * * *$ & 0.0012 & 0.0012 & -0.009 & -0.009 \\
\hline & $(3.41)$ & $(3.41)$ & $(1.64)$ & $(1.63)$ & $(1.42)$ & $(1.42)$ \\
\hline \multirow[t]{2}{*}{ Aid $*$ aid } & 0.001 & 0.001 & $-0.041^{* * *}$ & $-0.041^{* *}$ & $-0.002^{*}$ & $-0.002^{*}$ \\
\hline & $(1.11)$ & $(1.11)$ & $(2.58)$ & $(2.51)$ & $(1.64)$ & $(1.64)$ \\
\hline \multirow[t]{2}{*}{ Investment } & $-0.08^{* * *}$ & $-0.08^{* * *}$ & $-0.04^{* * *}$ & $-0.04^{* * *}$ & -0.01 & -0.01 \\
\hline & $(5.32)$ & $(5.32)$ & $(4.72)$ & $(4.72)$ & $(1.62)$ & $(1.62)$ \\
\hline \multirow[t]{2}{*}{ Intra-ECOWAS trade } & 0.023 & 0.023 & $0.029 * *$ & $0.029 * * *$ & 0.039 & $0.039 *$ \\
\hline & $(1.23)$ & $(1.23)$ & $(2.55)$ & $(2.59)$ & $(1.63)$ & $(1.65)$ \\
\hline \multirow[t]{2}{*}{ Broad money supply } & 0.003 & 0.003 & $0.028^{* * *}$ & $0.028^{* * *}$ & -0.007 & -0.007 \\
\hline & $(1.6)$ & $(1.6)$ & $(3.31)$ & $(3.31)$ & $(1.45)$ & $(1.45)$ \\
\hline \multirow[t]{2}{*}{ Trend } & $-0.009^{*}$ & -0.009 & $-0.031^{* * *}$ & $-0.031^{* * *}$ & 0.038 & $0.038^{*}$ \\
\hline & $(1.71)$ & $(1.71)$ & $(4.32)$ & $(431)$ & $(1.62)$ & $(1.64)$ \\
\hline \multirow[t]{2}{*}{ War } & - & - & $0.089^{* * *}$ & $0.089 * * *$ & -0.437 & -0.437 \\
\hline & & & $(3.89)$ & $(3.89)$ & $(0.54)$ & $(0.54)$ \\
\hline \multirow[t]{2}{*}{ UEMOA } & - & - & $-0.003^{*}$ & $-0.003^{* *}$ & 0.061 & 0.061 \\
\hline & & & $(1.64)$ & $(1.97)$ & $(1.15)$ & $(1.15)$ \\
\hline \multirow[t]{2}{*}{ Corruption_1994 } & - & - & - & - & 5.020 & 5.020 \\
\hline & & & & & $(1.62)$ & $(1.62)$ \\
\hline \multirow[t]{2}{*}{$c$} & $8.796^{* * *}$ & $8.796^{* * *}$ & $-14.151^{* * *}$ & $-14.151^{* * *}$ & -9.156 & -9.156 \\
\hline & $(3.25)$ & $(3.25)$ & $(4.13)$ & $(4.13)$ & $(1.01)$ & $(1.01)$ \\
\hline Number of countries & 14 & 14 & 14 & 14 & 14 & 14 \\
\hline Observations & 406 & 406 & 406 & 406 & 406 & 406 \\
\hline Adjusted $R^{2}$ & 0.65 & 0.65 & 0.6 & 0.6 & 0.58 & 0.58 \\
\hline$F$ statistics & $140^{* * *}$ & $140^{* * *}$ & $113^{* * *}$ & $113^{* * *}$ & $133^{* * *}$ & $133^{* * *}$ \\
\hline
\end{tabular}

*** Indicates significance at the 1 percent level.

** Indicates significance at the 5 percent level.

* Indicates significance at the 10 percent level.

$t$ statistics are in parenthesis.

through this currency. In the aftermath of World War II, France needed a steady source of cheap raw materials to rebuild its war-torn economy. The CFA franc was hence introduced and imposed upon French territories, which were mostly spread across Western and Central Africa. This currency and the arrangements therewith associated place unwarranted restraints on economic development and international trade for these countries due to persistent and detrimental exchange rate misalignments.

There are studies in the literature showing that exchange rate misalignments can stall growth by curtailing investment (see [25-27] among others). The war dummy is significant and carries the expected negative sign only in variant III, while the dummy accounting for the correctness of the corruption perception index is insignificant and brings little, or no, improvement in the explanatory power of bmodl. The latter finding would suggest, on the other hand, that the proxies used for pre-1994 CPI values do not fundamentally constitute a nuisance to the outcomes of our empirical assessment.

The results discussed above, although preliminary, have hinted at the fact that intraregional trade has a positive and significant impact on the expansion of per capita income in the ECOWAS, whereas foreign aid acts as an inhibitor of growth in per capita income. Table 4 reports the findings from $b \bmod 2$ which essentially corroborate those from bmod 1 with the notable exception impacts of the marginal effects of foreign aid on per capita income. The latter model indicates positive and significant marginal effects, while the former suggests negative and significant marginal effects in all TSLS specifications. At this point, we leave this aspect of the discussion as it is. We will revisit it as we gain more insights into these differences when we assess the robustness of our findings in the next section. 
TABLE 8: Regression estimates: random effects specifications of bmod2. Dependent variable: income per capita (in natural logarithm).

\begin{tabular}{|c|c|c|c|c|c|c|}
\hline \multirow{2}{*}{ Independent variables } & \multicolumn{2}{|c|}{ I } & \multicolumn{2}{|c|}{ III } & \multicolumn{2}{|c|}{ III } \\
\hline & WRSE & PCSE & WRSE & PCSE & WRSE & PCSE \\
\hline \multirow[t]{2}{*}{ Aid } & $-0.019^{* * *}$ & $-0.019^{* * *}$ & -0.013 & -0.013 & $-0.004^{* *}$ & $-0.004^{* *}$ \\
\hline & $(4.11)$ & $(4.11)$ & $(1.12)$ & $(1.11)$ & $(2.31)$ & $(2.31)$ \\
\hline \multirow[t]{2}{*}{ Initial income } & $0.710^{* * *}$ & $0.710^{* * *}$ & $0.969^{* * *}$ & $0.969 * * *$ & $0.734^{* * *}$ & $0.734^{* * *}$ \\
\hline & $(5.23)$ & $(5.23)$ & $(4.41)$ & $(4.41)$ & $(4.85)$ & $(4.85)$ \\
\hline \multirow[t]{2}{*}{ Inflation } & -0.007 & -0.007 & $0.006^{* *}$ & $0.006^{* *}$ & $-0.001^{* *}$ & $-0.001^{* *}$ \\
\hline & $(1.08)$ & $(1.08)$ & $(1.72)$ & $(1.72)$ & $(1.81)$ & $(1.81)$ \\
\hline \multirow[t]{2}{*}{ Corruption } & $0.148^{* * *}$ & $0.148^{* * *}$ & 0.029 & 0.029 & $0.200^{* * *}$ & $0.200^{* * *}$ \\
\hline & $(3.39)$ & $(3.39)$ & $(1.04)$ & $(1.04)$ & $(2.82)$ & $(2.82)$ \\
\hline \multirow[t]{2}{*}{ Corruption $*$ aid } & $0.0001^{*}$ & $0.0001^{*}$ & 0.003 & 0.003 & -0.06 & -0.06 \\
\hline & $(1.67)$ & $(1.68)$ & $(1.33)$ & $(1.33)$ & $(1.22)$ & $(1.22)$ \\
\hline \multirow[t]{2}{*}{ Aid $*$ aid } & 0.004 & 0.004 & -0.001 & -0.001 & $-0.005^{* *}$ & $-0.005^{* *}$ \\
\hline & $(1.42)$ & $(1.42)$ & $(1.13)$ & $(1.13)$ & $(2.07)$ & $(2.07)$ \\
\hline \multirow[t]{2}{*}{ Investment } & 0.01 & 0.01 & $-0.04^{* * *}$ & $-0.04^{* * *}$ & 0.02 & 0.02 \\
\hline & $(0.79)$ & $(0.79)$ & $(3.31)$ & $(3.31)$ & $(1.05)$ & $(1.04)$ \\
\hline \multirow[t]{2}{*}{ World trade } & $0.002^{* * *}$ & $0.002 * * *$ & -0.003 & $-0.003^{*}$ & $0.007^{*}$ & $0.007^{*}$ \\
\hline & $(5.53)$ & $(5.53)$ & $(1.61)$ & $(1.64)$ & $(1.67)$ & $(1.67)$ \\
\hline \multirow[t]{2}{*}{ Broad money supply } & 0.002 & 0.002 & $2.788^{* * *}$ & $2.788^{* * *}$ & $0.001^{* * *}$ & $0.001^{* * *}$ \\
\hline & $(0.25)$ & $(0.25)$ & $(4.81)$ & $(4.81)$ & $(3.39)$ & $(3.39)$ \\
\hline \multirow[t]{2}{*}{ Trend } & -0.002 & $-0.002^{*}$ & $-0.034^{* * *}$ & $-0.034^{* * *}$ & -0.034 & -0.034 \\
\hline & $(1.41)$ & $(1.69)$ & $(3.12)$ & $(3.12)$ & $(1.07)$ & $(1.07)$ \\
\hline \multirow[t]{2}{*}{ War } & - & - & 0.089 & 0.089 & $-0.122^{* * *}$ & $-0.122^{* * *}$ \\
\hline & & & $(1.61)$ & $(1.61)$ & $(2.97)$ & $(2.97)$ \\
\hline \multirow[t]{2}{*}{ UEMOA } & - & - & -0.003 & $-0.003^{*}$ & $-0.167^{* * *}$ & $-0.167^{* * *}$ \\
\hline & & & $(1.61)$ & $(1.68)$ & $(2.57)$ & $(2.57)$ \\
\hline \multirow[t]{2}{*}{ Corruption_1994 } & - & - & - & - & $0.012^{*}$ & 0.012 \\
\hline & & & & & $(1.65)$ & $(1.62)$ \\
\hline \multirow[t]{2}{*}{$c$} & $1.159^{* * *}$ & $1.159^{* * *}$ & $-14.151^{* * *}$ & $-14.151^{* * *}$ & $1.048^{* * *}$ & $1.048^{* * *}$ \\
\hline & $(4.17)$ & $(4.17)$ & $(5.55)$ & $(5.55)$ & $(5.41)$ & $(5.41)$ \\
\hline Number of countries & 14 & 14 & 14 & 14 & 14 & 14 \\
\hline Observations & 406 & 406 & 406 & 406 & 406 & 406 \\
\hline Adjusted $R^{2}$ & 0.68 & 0.68 & 0.75 & 0.75 & 0.74 & 0.74 \\
\hline$F$ statistics & $257^{* * *}$ & $257^{* * *}$ & $261^{* * *}$ & $261^{* * *}$ & $241^{* * *}$ & $241^{* * *}$ \\
\hline
\end{tabular}

${ }^{* * *}$ Indicates significance at the 1 percent level.

** Indicates significance at the 5 percent level.

* Indicates significance at the 10 percent level.

$t$ statistics are in parenthesis.

By enlarging the scope of trade to include the rest of the world, $b$ mod 2 provides added values in our understanding of the comparative impacts of trade and foreign aid on income per capita. Both intra-ECOWAS trade and trade with the rest of the world stimulate income per capita as opposed to foreign aid that reduces it. Even under the best circumstances where corruption is eradicated or contained, trade remains markedly superior in positively affecting changes in per capita income.

4.1. Robustness Assessment: Fixed and Random Effects Anal$y$ sis. There is a chance that our initial findings exhibit some weaknesses or inconsistencies as country specific, and random effects are accounted for. The present step is essential in this study because of the high likelihood of obtaining spurious results when a diverse group of countries is pooled together across time. Tables $5-8$ present the results found using the white robust standard errors (WRSEs) and panel corrected standard errors (PCSEs) procedures to correct for serial correlations. Although results appear globally similar, the identification and computing procedures underlying each of them remain distinct. These distinctions arise from the variance structure considered for disturbances. As a matter of fact, the former procedure provides results that are robust to both arbitrary serial correlation and time-varying variances in the disturbances [28]. The latter derives outputs that are robust to unrestricted unconditional variances. In this case, residuals are replaced by moment estimators for the unconditional variances.

Findings from the fixed and random effects models corroborate the bulk of our preliminary results in Tables 3 and 4. Coefficients associated with aid and intra-ECOWAS trade are significant and display signs that are consistent with our previous findings. The notable exceptions are the 
respective magnitudes of different coefficients, which appear to be larger in general for the relevant variables in this work, when significant. In other words, both the positive and negative impacts of intraregional trade and foreign aid, respectively, are magnified when country-specific and sampling characteristics are taken into consideration. This consistency is perceived across the different variants of our baseline model. Intra-ECOWAS trade is found to be a driving force behind income per capita growth in the region, while aid remains an impediment to this growth. Similar observations are made in the case of trade with the rest of the world.

Once the problem of corruption is rooted out, or addressed, we find that foreign aid has positive but insignificant effects on per capita income in variants I of both specifications, while variants II and III denote negative and significant effects in both baseline models (Tables 5 and 6). Random effects specifications, however, note some positive and significant effects in variants I only, when the other variants show insignificance regardless of the sign. Again, these latest results show that in the best possible settingswhere aid bears positive and significant signs-its impact on per capita income is consistently immaterial.

Moreover, the marginal effects of aid on per capita income are negative and significant in all variants. These findings are observed as well with random effects specifications when coefficients are significant. This settles the apparent differences perceived in the previous section confirming thereby that the marginal effects of aid on per capita income are negative. This outcome lends additional support to the argument that foreign aid is ineffective as the latest foreign aid dollar received persistently stymies any expansion in per capita income. To sum up our results, we notice that foreign aid exerts some negative effects on changes in income per capita in the ECOWAS, which is one essential barometer in the measurement of their performances in their struggle against widespread poverty. In specifications where aid positively affects income per capita, it remains negligible compared to intraregional trade which remains more impactful in most instances. Besides, these results are upheld through bmod2 when we broaden our scope to include trade with the rest of the world instead. It is referred to as world trade in result tables and its definition is clarified in Table 9.

There exist a few reasons that could help shed light on the impotence of aid in stimulating income per capita in the ECOWAS member countries in particular and Africa's developing countries in general. First, it is a well-known fact that a great deal of aid given to these developing countries is not open ended. The bulk of foreign aid either comes with strings attached or is earmarked for initiatives or programs that are not directly growth enhancers. Foreign aid directed toward military programs and the accommodations of shortfalls in government revenues, or balance of payments, abounds. For instance, Egypt has been receiving from the United States about $\$ 2$ billion a year in aid-much of it as military aid-since the late 1970s (source: News Agency Reuters, January 29, 2011. Figures were reported from the Congressional Research Service).
Second, donor countries oftentimes require that recipient countries utilize part or all of the aid proceeds to secure goods from corporations headquartered in these donor countries. In this regard, these aids are comparable to a back channel subsidizing mechanism of donor countries to their domestic corporations or industries.

Third, notwithstanding the poor economic performances compounded with poor governance in a developing country, the donor country will keep on extending aid to this country provided that the donor country's interests are stewarded. These interests can be shaped by diplomatic, military, linguistic as well as historical relationships between the donor and recipient countries.

As an illustration, all UEMOA member countries are former French colonies excepting Guinea-Bissau. For more than 3 decades, France has given these countries a preferential treatment in its allocation of foreign aid. The purposes of these aids are multiform. They are aimed at safeguarding and advancing their interests, while shoring up friendly leaders' grip onto power in what is commonly dubbed the "french backyard" in Africa. This concept is closely related to another terminology, the "Françafrique," which refers to the group of all former french colonies in sub-Saharan Africa where France's political and economic influences remain well established and virtually unchallenged until this day. Corporations (such as Bouygues, Bolloré, and France Télécom) and banking institutions (such as Sociéte Générale, Crédit Lyonnais, and BNP Paribas), among others, have been enjoying a quasimonopoly status in all key sectors of these economies for decades.

At last, foreign aid constitutes one of the vectors that feed capital flight out of Africa. Ndikumana and Boyce [29, page 60] use the insightful concept of "revolving door" to expose this state of affairs that is highly detrimental to economic development on the continent of Africa. Their empirical work reveals that aid has not been immune from the "operation of the revolving door" [30, page 67]. Moreover, embezzlements of foreign aid proceeds by heads of states, their close associates or government officials are not uncommon. These proceeds wind up ballooning the national debt of these countries, which must be serviced using already scanty government revenues.

\section{Conclusion}

Evidence from this study suggests that foreign aid is not an engine of growth for per capita output in the ECOWAS, but it rather acts as an impediment. At the same time, the prevalence of aid creates a culture of permanent dependency on foreign donors that may reduce incentives to conduct and implement viable macroeconomic and trade policies. Trade within the ECOWAS, to the contrary, is a robust factor that promotes expansion in output per capita, which is necessary to achieve palpable results in the fight against poverty. Comparable results are expected if these countries pursue efforts to boost trade with the rest of the world. This analysis provides an additional basis for recommending policies that reduce administrative red tapes and create an environment that is adequate for the development of intra-ECOWAS 
TABle 9: Data description.

\begin{tabular}{lll}
\hline Variable & Definition & Source \\
\hline Income per capita & RGDP per capita & (The) World Bank [10] \\
Aid & Net ODA as a percentage of GDP & (The) World Bank [10] \\
Initial income & Initial real GDP per capita & (The) World Bank [10] \\
Inflation & Changes in the consumer price level & (The) World Bank [10] \\
Corruption & Corruption perception index (CPI) & Transparency International \\
Investment & Gross formation of fixed capital as a share of GDP & (The) World Bank [10] \\
Intra-ECOWAS trade & Imports and exports to and from any member country as a share of GDP & UNCTAD [23] \\
World trade population & Volume of trade with the world, excluding ECOWAS, as a share of GDP & UNCTAD \\
& Number of inhabitants & (The) World Bank [10, 23] \\
Broad money supply & M2 as a share of GDP & (The) World Bank [10] \\
War & War dummy & CFA franc dummy \\
UEMOA & CPI accuracy dummy & - \\
Corruption_1994 & & -
\end{tabular}

trade. Diversifying the industrial base and building an infrastructure network - that supports and facilitates trade in general and regional trade in particular-will generate numerous positive externalities throughout local economies and the region.

From another perspective, our results highlight an economic fact that has been discussed throughout the history of economic thoughts. The success of a nation on the road to prosperity and economic development is rooted in that nation's ability to create riches and engage in trade with other nations. Only through that singular process have nations become economic powers and been able to durably lift up their peoples out of poverty. As an illustration among many, one may allude to the fact that Côte d'Ivoire had the same GDP per capita as South Korea when she gained independence from France in 1960. However, it is apparent today that South Korea has achieved a level of development and a standard of living far superior to those of Côte d'Ivoire. Indeed, over the decades South Korea implemented, among other things, policies aimed at boosting her competitiveness and involvement in international trade (both regional and non-regional). In 2010, the GDP per capita of South Korea was more than 16 times Côte d'Ivoire's (CIA World Factbook, 2011).

\section{Appendix}

(i) Fixed Effects Models. bmod1

$$
\begin{gathered}
w_{i t}=F_{i}+\delta_{1} S_{i t}+\theta_{1} N_{i t}+\pi_{1} L_{i t}+\psi_{i t}, \\
\operatorname{irt}_{i t}=Q_{i}+\delta_{2} S_{i t}+\theta_{2} N_{i t}+\eta_{i t},
\end{gathered}
$$

where $F_{i}$ and $Q_{i}$ are, respectively, the country-specific effects for growth and intraregional trade in our panel data; $\psi_{i t}$ and $\eta_{i t}$ are error terms defined such that $E\left(\psi_{i t}\right) \sim N\left(0, \sigma_{\psi}{ }^{2}\right)$ and $E\left(\eta_{i t}\right) \sim N\left(0, \sigma_{\eta}{ }^{2}\right)$. Similar transformations are made for bmod2. (ii) Random Effects Models. bmod1

$$
\begin{gathered}
w_{i t}=\lambda_{i}+\delta S_{i t}+\theta N_{i t}+\pi L_{i t}+\xi_{i t}, \\
\operatorname{irt}_{i t}=\alpha_{i}+\alpha_{1} S_{i t}+\alpha_{2} N_{i t}+\kappa_{i t} .
\end{gathered}
$$

For empirical purposes, (A.3) are transformed as follows:

$$
\begin{gathered}
w_{i t}=\lambda+\delta S_{i t}+\theta N_{i t}+\pi L_{i t}+\vartheta_{i t} \\
\operatorname{irt}_{i t}=\alpha+\alpha_{1} S_{i t}+\alpha_{2} N_{i t}+\varsigma_{i t}
\end{gathered}
$$

where $9 i t=\ddot{v}_{i}+\xi_{i t}$ and $\varsigma_{i t}=\dot{v}_{i}+\kappa_{i t}$;

$$
\lambda_{i}=\lambda+\ddot{v}_{i}, \quad \alpha_{i}=\alpha+\dot{v}_{i} .
$$

$\ddot{v}_{i}$ and $\hat{v}_{i}$ are random error terms with a mean value of 0 and variances $\sigma_{\ddot{v}}^{2}$ and $\sigma_{i i}^{2}$, respectively; $E\left(\ddot{v}_{i} \xi_{i t}\right)=0$ and $E\left(\dot{v}_{i} \kappa_{i t}\right)=$ 0 . Similar transformations are made for bmod2.

\section{(iii) Hausman Endogeneity Test}

(1) The following reduced-form equation are used to derive the estimated values of $\chi_{i t}$ and $\varphi_{i t}$ :

$$
\begin{aligned}
\operatorname{irt}_{i t}= & \rho_{1,1}+\rho_{1,2}(\text { aid })_{i t}+\rho_{1,3} \ln (\text { init_inc })_{i t} \\
& +\rho_{1,4}(\text { inflation })_{i t}+\rho_{1,5}(\text { corruption })_{i t} \\
& +\rho_{1,6}(\text { corruption } * \text { aid })_{i t}+\rho_{1,7}(\text { aid } * \text { aid })_{i t} \\
& +\rho_{1,8}(\text { investment })_{i t}+\rho_{1,9}(\text { broad_money })_{i t} \\
& +\rho_{1,10}(\text { trend })_{i t}+\rho_{1,11} \ln (\text { population }) \\
& +\rho_{1,12} \ln (\text { population })^{2}+\rho_{1,13}(\text { war })_{i t}
\end{aligned}
$$




$$
\begin{aligned}
& +\rho_{1,14}(\mathrm{UEMOA})_{i t}+\rho_{1,15}(\text { corruption_1994 })_{i t} \\
& +\chi_{i t}
\end{aligned}
$$

$$
\begin{aligned}
\operatorname{row}_{i t}= & \sigma_{1,1}+\sigma_{1,2}(\text { aid })_{i t}+\sigma_{1,3} \ln (\text { init_inc })_{i t} \\
& +\sigma_{1,4}(\text { inflation })_{i t}+\sigma_{1,5}(\text { corruption })_{i t} \\
& +\sigma_{1,6}(\text { corruption } * \text { aid })_{i t}+\sigma_{1,7}(\text { aid } * \text { aid })_{i t} \\
& +\sigma_{1,8}(\text { investment })_{i t}+\sigma_{1,9}(\text { broad_money })_{i t} \\
& +\sigma_{1,10}(\text { trend })_{i t}+\sigma_{1,11} \ln (\text { population }) \\
& +\sigma_{1,12} \ln (\text { population })^{2}+\sigma_{1,13}(\text { war })_{i t} \\
& +\sigma_{1,14}(\text { UEMOA })_{i t} \\
& +\sigma_{1,15}(\text { corruption_1994 })_{i t}+\varphi_{i t .} .
\end{aligned}
$$

(2) Equation (A.7) below are then run

$$
\begin{aligned}
w_{i t}= & \tau_{1,1}+\tau_{1,2}(\text { aid })_{i t}+\tau_{1,3} \ln (\text { init_inc })_{i t} \\
& +\tau_{1,4}(\text { inflation })_{i t}+\tau_{1,5}(\text { corruption })_{i t} \\
& +\tau_{1,6}(\text { corruption } * \text { aid })_{i t}+\tau_{1,7}(\text { aid } * \text { aid })_{i t} \\
& +\tau_{1,8}(\text { investment })_{i t}+\tau_{1,10}(\text { broad_money })_{i t} \\
& +\tau_{1,11}(\text { trend })_{i t}+\tau_{1,12}(\text { war })_{i t} \\
& +\tau_{1,13}(\text { UEMOA })_{i t}+\tau_{1,14}(\text { corruption_1994 })_{i t} \\
& +\tau_{1,15} \hat{\chi}_{i t}+\phi_{i t}, \\
w_{i t}= & \xi_{1,1}+\xi_{1,2}(\text { aid })_{i t}+\xi_{1,3} \ln (\text { init_inc })_{i t} \\
& +\xi_{1,4}(\text { inflation })_{i t}+\xi_{1,5}(\text { corruption })_{i t} \\
& +\xi_{1,6}(\text { corruption } * \text { aid })_{i t}+\xi_{1,7}(\text { aid } * \text { aid })_{i t} \\
& +\xi_{1,8}(\text { investment })_{i t}+\xi_{1,10}(\text { broad_money })_{i t} \\
& +\xi_{1,11}(\text { trend })_{i t}+\xi_{1,12}(\text { war })_{i t}+\xi_{1,13}(\mathrm{UEMOA})_{i t} \\
& +\xi_{1,14}(\text { corruption_1994 })_{i t}+\xi_{1,15} \widehat{\varphi}_{i t}+\mho_{i t .}
\end{aligned}
$$

\section{References}

[1] W. Easterly, "Can foreign aid buy growth?” Journal of Economic Perspectives, vol. 17, no. 3, pp. 23-48, 2003.

[2] C. Burnside and D. Dollar, "Aid, policies, and growth," American Economic Review, vol. 90, no. 4, pp. 847-868, 2000.

[3] D. K. Leonard and S. Straus, Africa's Stalled Development, Lynne Rienner, Boulder, Colo, USA, 2003.

[4] R. Ilorah, "Trade, aid and national development in Africa," Development Southern Africa, vol. 25, no. 1, pp. 83-98, 2008.

[5] D. K. Leonard and S. Straus, Africa's Stalled Development, Lynne Rienner, Boulder, Colo, USA, 2003.

[6] R. M. Quazi, "Effects of foreign aid on GDP growth and fiscal behavior: an econometric case study of Bangladesh," The Journal of Developing Areas, vol. 38, no. 2, pp. 95-117, 2005.

[7] J. A. Frankel and D. Romer, "Does trade cause growth?" American Economic Review, vol. 89, no. 3, pp. 379-399, 1999.
[8] J. Younas, "Motivation for bilateral aid allocation: altruism or trade benefits," European Journal of Political Economy, vol. 24, no. 3, pp. 661-674, 2008.

[9] J. Younas and S. Bandyopadhyay, "Do donors care about declining trade revenue from liberalization? An analysis of bilateral aid allocation," Federal Reserve Bank of St. Louis Review, vol. 91, no. 3, pp. 141-154, 2009.

[10] The World Bank, World Development Indicators, The World Bank, Washington, DC, USA, 2012.

[11] H. Hansen and F. Tarp, "Aid and growth regressions," Credit Research Papers No. 00/7, Centre for Research in Economic Development and International Trade, University of Nottingham, 2000.

[12] L. Ndikumana and J. K. Boyce, Africa's Odious Debts, Zed Books, New York, NY, USA, 2011.

[13] B. T. Elmslie, "The convergence debate between david hume and josiah tucker," Journal of Economic Perspectives, vol. 9, no. 4, pp. 207-216, 1995.

[14] J. W. Fedderke, P. Perkins, and J. M. Luiz, "Infrastructural investment in long-run economic growth: South Africa 18752001," World Development, vol. 34, no. 6, pp. 1037-1059, 2006.

[15] E. Hernández-Catá, "Raising growth and investment in subsaharan Africa: what can be done?" Finance and Development, vol. 37, no. 4, pp. 30-33, 2000.

[16] Y. Hadiwibowo, "Fiscal policy, investment and long-run economic growth: evidence from Indonesia," Asian Social Sciences, vol. 6, no. 9, pp. 3-11, 2010.

[17] R. Pollin and A. Zhu, "Inflation and economic growth: a crosscountry nonlinear analysis," Journal of Post Keynesian Economics, vol. 28, no. 4, pp. 593-614, 2006.

[18] Q. Munir and K. Mansur, "Non-linearity between inflation rate and GDP growth in Malaysia," Economics Bulletin, vol. 29, no. 3, pp. 1551-1565, 2009.

[19] H. Hughes, "Trade, aid and development," Australian Economic Review, vol. 39, no. 1, pp. 63-68, 2006.

[20] Y. Yang and S. Gupta, "Regional trade arrangements in Africa: past performance and the way forward," African Development Review, vol. 19, no. 3, pp. 399-431, 2007.

[21] J. Gourdon, "Explaining trade flows: traditional and new determinants of trade patterns," Munich Personal RePEc Archive, Paper No. 4175, 2006.

[22] J. A. Hausman, "Specification tests in econometrics," Econometrica, vol. 46, pp. 1251-1271, 1976.

[23] United Nations Conference on Trade and Development (UNCTAD), UNCTADStat, Geneva, Switzerland, 1964.

[24] N. Agbohou, in Le Franc CFA et l'Euro contre l'Afrique, Solidarité Mondiale A.S. , Paris, France, 1999.

[25] T. Dosse, "Real exchange rate misalignment and economic growth in developing countries," Southwestern Economic Review, vol. 33, no. 1, pp. 57-72.

[26] I. Koske, "Assessing the equilibrium exchange rate of the Malaysian ringgit: a comparison of alternative approaches," Asian Economic Journal, vol. 22, no. 2, pp. 179-208, 2008.

[27] N. Giannellis and A. P. Papadopoulos, "Estimating the equilibrium effective exchange rate for potential EMU members," Open Economies Review, vol. 18, no. 3, pp. 307-326, 2007.

[28] H. L. White, "A heteroskedasticity-consistent covariance matrix estimator and a direct test for heteroskedasticity," Econometrica, vol. 48, no. 4, pp. 817-838, 1980.

[29] L. Ndikumana and J. K. Boyce, Africa's Odious Debts, Zed Books, New York, NY, USA, 2011.

[30] L. Ndikumana and J. K. Boyce, Africa's Odious Debts, Zed Books, New York, NY, USA, 2011. 


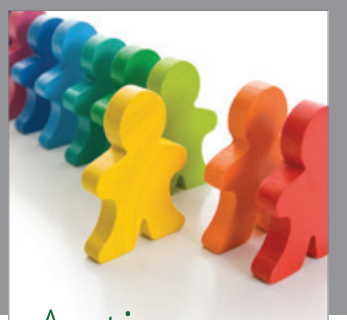

Autism

Research and Treatment
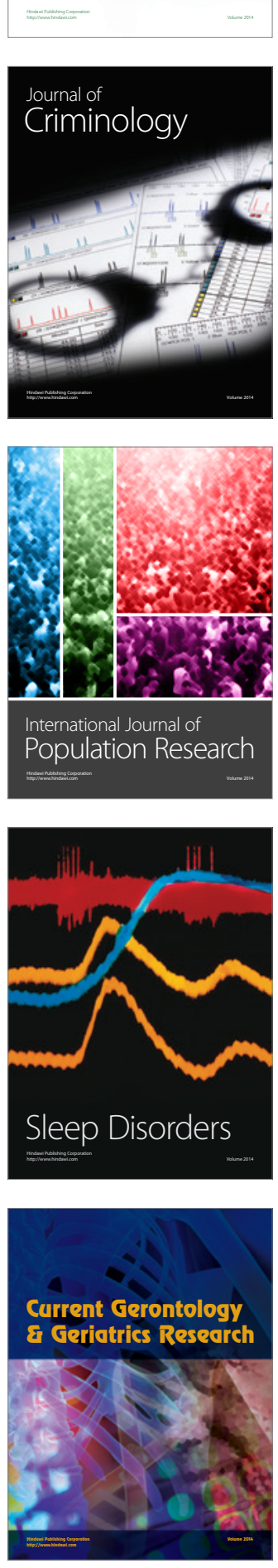
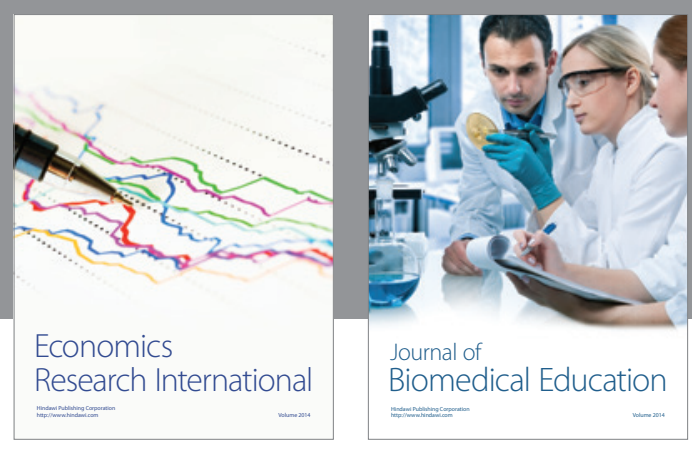

Journal of

Biomedical Education

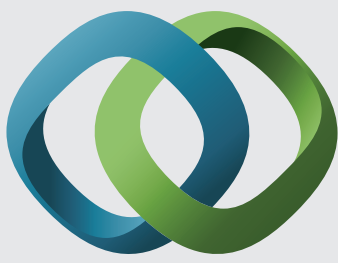

\section{Hindawi}

Submit your manuscripts at

http://www.hindawi.com
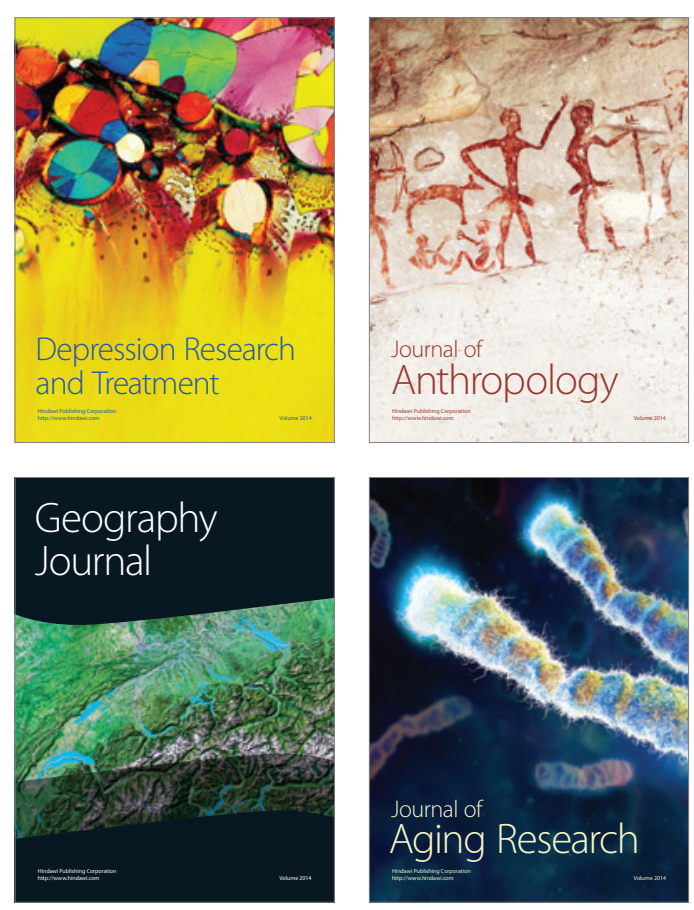

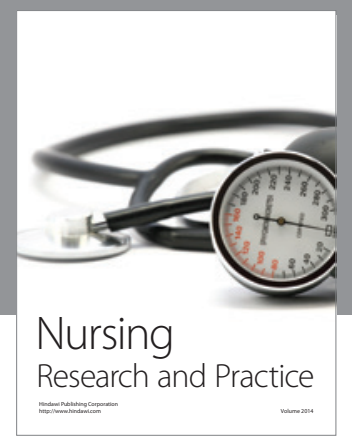

Nursing

Research and Practice

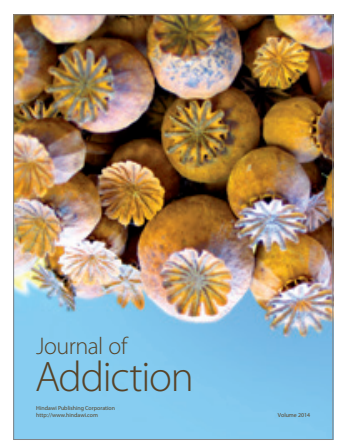

Child Development

Research

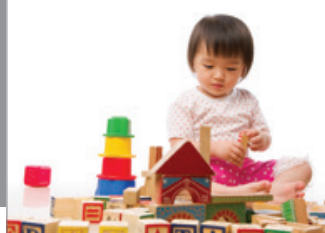

迥
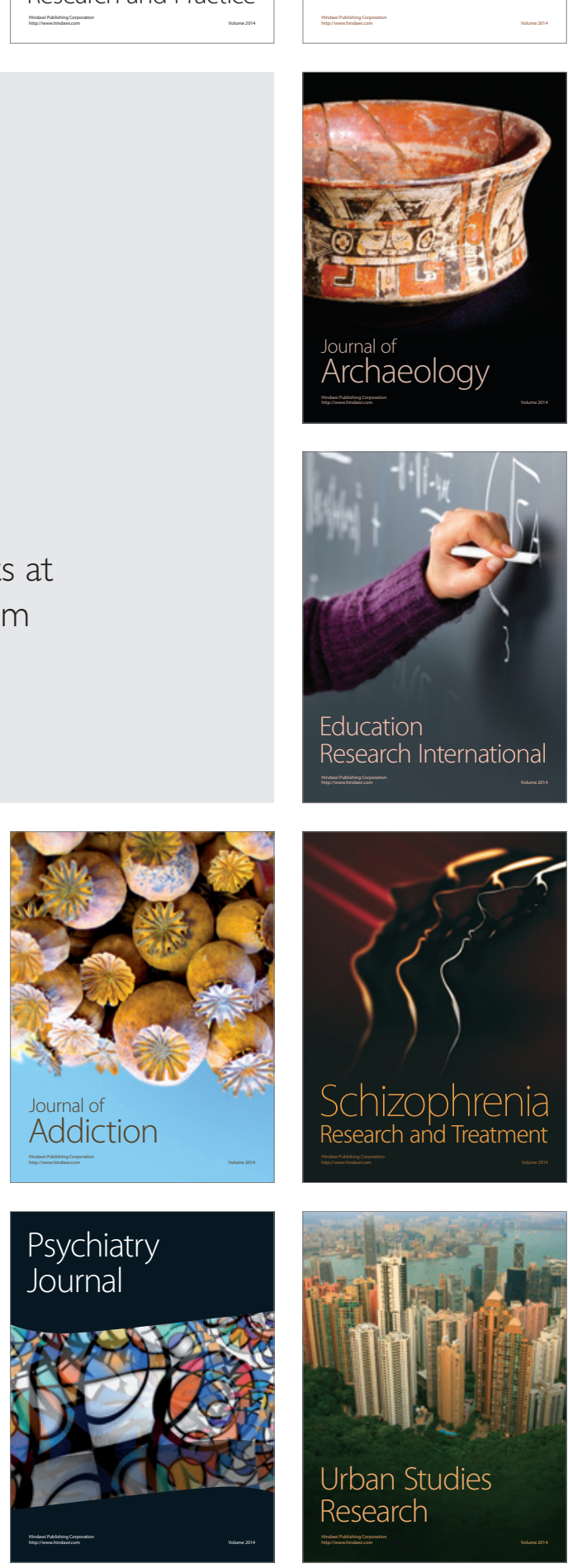